OPEN ACCESS

Edited by:

Xiao Li,

Texas Heart Institute, United States

Reviewed by:

Tijana Mitic,

University of Edinburgh

United Kingdom

Chien-Ling Huang,

Hong Kong Polytechnic University,

China

*Correspondence:

Philip A. Marsden

p.marsden@utoronto.ca

Specialty section:

This article was submitted to

$R N A$

a section of the journal

Frontiers in Genetics

Received: 16 February 2021

Accepted: 17 May 2021

Published: 26 August 2021

Citation:

Subramaniam N, Nair $R$ and

Marsden PA (2021) Epigenetic

Regulation of the Vascular

Endothelium by Angiogenic LncRNAs.

Front. Genet. 12:668313.

doi: 10.3389/fgene.2021.668313

\section{Epigenetic Regulation of the Vascular Endothelium by Angiogenic LncRNAs}

\author{
Noeline Subramaniam 1,2, Ranju Nair ${ }^{2,3}$ and Philip A. Marsden 1,2,3,4* \\ ${ }^{1}$ Marsden Lab, Institute of Medical Sciences, University of Toronto, Toronto, ON, Canada, ${ }^{2}$ Marsden Lab, Keenan Research \\ Centre in the Li Ka Shing Knowledge Institute, St. Michael's Hospital, Toronto, ON, Canada, ${ }^{3}$ Marsden Lab, Department of \\ Laboratory Medicine and Pathobiology, University of Toronto, Toronto, ON, Canada, ${ }^{4}$ Department of Medicine, University \\ of Toronto, Toronto, ON, Canada
}

The functional properties of the vascular endothelium are diverse and heterogeneous between vascular beds. This is especially evident when new blood vessels develop from a pre-existing closed cardiovascular system, a process termed angiogenesis. Endothelial cells are key drivers of angiogenesis as they undergo a highly choreographed cascade of events that has both exogenous (e.g., hypoxia and VEGF) and endogenous regulatory inputs. Not surprisingly, angiogenesis is critical in health and disease. Diverse therapeutics target proteins involved in coordinating angiogenesis with varying degrees of efficacy. It is of great interest that recent work on non-coding RNAs, especially long non-coding RNAs (IncRNAs), indicates that they are also important regulators of the gene expression paradigms that underpin this cellular cascade. The protean effects of IncRNAs are dependent, in part, on their subcellular localization. For instance, IncRNAs enriched in the nucleus can act as epigenetic modifiers of gene expression in the vascular endothelium. Of great interest to genetic disease, they are undergoing rapid evolution and show extensive inter- and intra-species heterogeneity. In this review, we describe endothelial-enriched IncRNAs that have robust effects in angiogenesis.

Keywords: endothelial cell, IncRNA, angiogenesis, epigenetics, gene regulation, vascular

\section{INTRODUCTION}

The cardiovascular system is a complex and dynamic network of blood vessels pumping blood from the heart to the rest of the body. Through the blood vessels, nutrients and oxygen are delivered to the cells, and carbon dioxide and waste products are removed. This occurs at a rapid rate in advanced species, and to maintain this, there is a tight interplay of multiple hemodynamic forces including circumferential stretch, hydrostatic pressure, shear stress and rates of blood flow. At the interface between the circulating blood and the vascular wall is the vascular endothelium, acting as a dynamic barrier. The endothelium is a monolayer of endothelial cells (ECs) that lines the entire closed cardiovascular system. We have previously argued that ECs are professional sensors of hemodynamic forces (Ku et al., 2019). ECs sense and respond to these forces, which in turn affect EC phenotype.

A finite number of cis-DNA elements and associated trans-factors mediate the nuclear-based response to the interplay of these varied hemodynamic factors. One such cis-DNA element that is activated by atheroprotective, laminar flow is the shear stress response element (SSRE), which was first identified in the promoter region of platelet-derived growth factor-B (PDGF-B) (Resnick et al., 1993). We now know that the SSRE is detected in many other flow-regulated EC 
genes such as intercellular adhesion molecule 1 (ICAM1), endothelin-1 (ET-1/EDN1), monocyte chemoattractant protein 1 (MCP1)/chemokine (C-C motif) ligand 2 (CCL2), and the prototypic EC gene responsible for nitric oxide production, endothelial nitric oxide synthase (eNOS) (Ku et al., 2021). Another important flow-regulated cis-DNA element is Krüppellike factor (KLF). The KLFs are zinc-finger transcription factors (Anderson et al., 1995). In particular, it is known that KLF2 and KLF4 are important flow-regulated transcription factors that signal through the MEF5/ERK5/MEF2 pathway to mediate transcription of many flow-responsive genes (Dekker et al., 2002b; Parmar et al., 2005; Ohnesorge et al., 2010; Le et al., 2013; Sangwung et al., 2017). KLF2 regulates vascular tone by inducing expression of eNOS (Dekker et al., 2005; Parmar et al., 2005). Models of atherosclerosis confirm the critical role for these KLF transcription factors in vascular homeostasis. In apolipoprotein E (ApoE) deficient mice with hemizygous KLF2 deficiency, there is a notable increase in atherosclerosis (Atkins et al., 2008). Similar results are observed with EC-specific loss of KLF4 in ApoE deficient mice (Zhou et al., 2012). Together, these studies demonstrate an important atheroprotective role for KLF2 and KLF4. Finally, there is the myocyte enhancer factor- 2 (MEF2) family, members of which bind to the promoter region of KLF2 and regulate its expression under shear stress (Kato et al., 1997; Parmar et al., 2005; Wang et al., 2010). EC-specific deletions in mice of MEF2 factors, Mef2a, $-c$, and -d, disrupt vascular homeostasis (Lu et al., 2021). Combined deletion of these MEF2 factors significantly decreased KLF2/KLF4 expression. In summary, these independent cis-DNA elements, namely the SSRE, KLF and MEF2 elements mediate transcriptional responses to changes in shear stress.

Adding to this classic cis-trans paradigm, EC gene expression is also regulated by epigenetic mechanisms. Broadly defined, epigenetics refers to chromatin-based mechanisms important in the regulation of gene expression that do not involve changes to the DNA sequence per se (Matouk and Marsden, 2008; Yan et al., 2010; Webster et al., 2013). Epigenetic mechanisms include DNA methylation, histone modifications and RNA-based mechanisms, including long non-coding RNAs (lncRNAs). They are highly responsive to changes in the environment, making them quite dynamic. Epigenetic mechanisms have profound effects on many biological processes in which ECs participate in, especially hemodynamic regulation and angiogenesis. Short non-coding RNAs, such as microRNAs (miRNAs), have been gaining scientists' attention for their post-transcriptional effects since the early 2000s (Battistella and Marsden, 2015). In recent years, a newer class of non-coding RNAs called long noncoding RNAs have emerged, and they have been shown to be important regulators of gene expression in health and disease. LncRNAs tend to be enriched in the nucleus, where they can act as epigenetic modifiers of gene expression (Man and Marsden, 2019). Some of the best studied lncRNAs are X-inactive specific transcript (XIST) which is known to inactivate one of the $\mathrm{X}$ chromosomes in females; HOX transcript antisense RNA (HOTAIR), which is involved in limb development; and antisense non-coding RNA in the Inhibitors of CDK4 (INK4) locus (ANRIL), which is strongly correlated with cardiovascular disease risk. The identification and characterization of angiogenic
lncRNAs has introduced the idea that lncRNAs may serve as biomarkers and/or therapeutic targets for diseases in which angiogenesis is disrupted, such as in cancers or cardiovascular disease. In this review, we will discuss how nuclear endothelialenriched lncRNAs, affect EC angiogenesis. We will especially highlight the STEEL, GATA6-AS and MANTIS IncRNAs.

\section{LONG NON-CODING RNAs}

Historically believed to be "transcriptional noise" or "dark matter," lncRNAs have emerged as key modulators of many biological processes. Scientists have identified thousands of lncRNAs, with the online database "LncBook" citing $>270,000$ lncRNAs in humans (Ma et al., 2019). However, the number of lncRNAs that have been functionally characterized is $\sim<1 \%$ of those identified (Quek et al., 2015). LncRNAs are primarily characterized by their length as $>200$ nucleotides long, mainly to distinguish this class of non-coding molecules from shorter transcripts (Mercer et al., 2009; Mattick and Rinn, 2015). LncRNAs can be $5^{\prime}$-capped, spliced, polyadenylated, and often have low expression levels relative to proteincoding genes (Guttman et al., 2009; Derrien et al., 2012). As their name suggests, they are not translated into proteins and thus, often have trivial or non-functional open reading frames (ORFs). This can be assessed through bioinformatic analysis of coding domain sequence, secondary structure, di/trinucleotide sequence frequencies and cross-species conservation (Ulitsky and Bartel, 2013; Ventola et al., 2017). LncRNAs can be classified based on several criteria, but broadly are often grouped by their organization relative to other genes, due to a lack of clarity on their sequence-structurefunction relationship. They can be described as intronic, intergenic, antisense, bidirectional, enhancer, or promoterassociated lncRNAs.

LncRNAs can be present in the nucleus, cytoplasm, or mitochondria, and they may also be secreted (Rackham et al., 2011; van Heesch et al., 2014; see Figure 1). A lncRNA can also be expressed in multiple compartments, such as GAS5, which is expressed in both the nucleus and the cytoplasm (Kino et al., 2010). Since subcellular localization often confers function, the mechanism of action of a lncRNA can be inferred, in part, by defining where they are targeted (Cai and Cullen, 2007; Quinodoz and Guttman, 2014; Romero-Barrios et al., 2018; Hou et al., 2019; Mishra and Kanduri, 2019; Rom et al., 2019). Nuclear lncRNAs like XIST or HOTAIR are often important mediators of regulating epigenetic mechanisms (Mercer et al., 2009). They can act in cis or in trans by interacting with neighboring or non-neighboring genes to exert their effects (Rinn et al., 2007; Wang et al., 2011; Engreitz et al., 2013; Novikova et al., 2013). Cytoplasmic lncRNAs like Tie1-AS can interact with proteincoding genes, and others still can act as a scaffold for proteinprotein interactions (Li et al., 2010). Many lncRNAs, including ones we will highlight in this review regulate gene expression through chromatin-based mechanisms.

Finally, non-coding RNAs can be enriched in particular cellor tissue-types. For example, spliced-transcript endothelialenriched lncRNA (STEEL) is an endothelial-enriched 


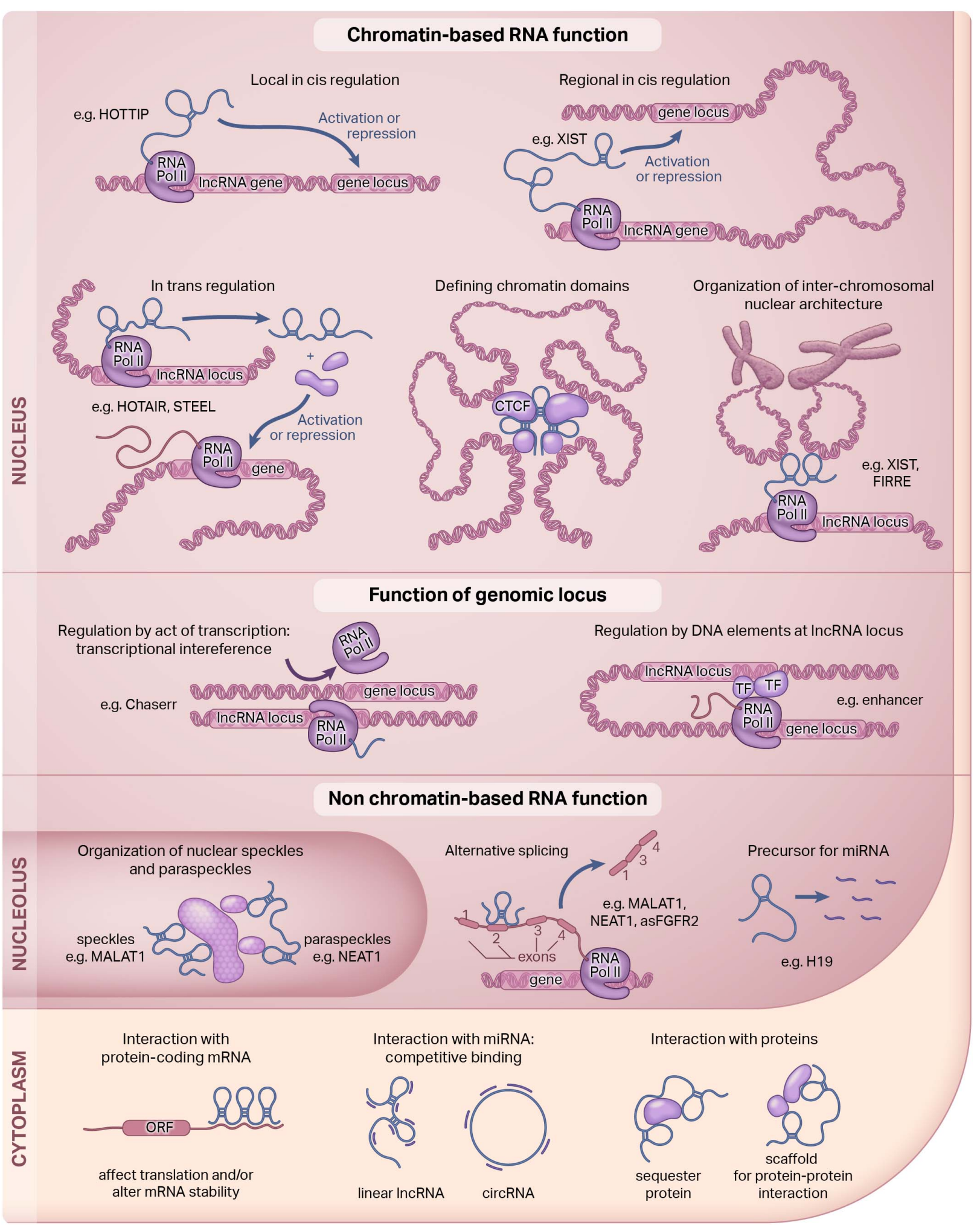

FIGURE 1 | Functions of long non-coding RNAs. Long non-coding RNAs (IncRNAs) are a diverse class of molecules that are distributed throughout the cell. The function of IncRNAs are dependent, in part, on their subcellular localization. Here, we illustrate known IncRNA functions in the nucleus and the cytoplasm. Our review focuses on the nuclear function of IncRNAs. This figure was adapted; it was originally published in Current Opinion in Pharmacology, Volume 45, Hon-Sum Jeffrey Man and Philip A Marsden, LncRNAs and epigenetic regulation of vascular endothelium: genome positioning system and regulators of chromatin modifiers, pp. 72-80, Copyright Elsevier, 2019. 
lncRNA that has EC-specific functions (Man et al., 2018). In contrast, there are lncRNAs like metastasis-associated lung adenocarcinoma transcript 1 (MALAT1) that is expressed at very high levels and is found widely across almost all cell types. Some lncRNAs are highly upregulated by environmental stimuli that are especially relevant to ECs, such as the lncRNA that enhances eNOS expression (LEENE), which is induced under physiological blood flow and pulsatile shear stress (Miao et al., 2018). Another example is GATA6-AS, which is hypoxiaresponsive (Neumann et al., 2018). Disease-associated lncRNAs have also been identified, with the best example being ANRIL (McPherson et al., 2007; Holdt et al., 2010; Congrains et al., 2012). Through genome-wide association studies (GWAS), exons 13-19 of ANRIL comprise a disease-associated haplotype noted for a marked increased risk of coronary artery disease (CAD). Now we know that it is also associated with other cardiovascular diseases, such as ischemic peripheral vascular disease and ischemic stroke (Zeggini et al., 2007; Foroud et al., 2012; Kremer et al., 2015; Kong et al., 2016; Tan et al., 2019). Evidently, lncRNAs are biologically important and functionally diverse.

\section{How to Detect IncRNAs}

There are many methods to identify lncRNAs, but microarrays were by far the method of choice for a long time-until the advent of deep RNA-sequencing (RNA-seq; Table 1; Mockler et al., 2005). While microarrays are high throughput, costeffective, and computationally manageable, they also limit novel lncRNA discovery due to pre-determined probe sets; optimal probe coverage and density; and background noise from cross-hybridizations or weak binding (Uchida, 2017). Deep RNA-seq has become the current method of choice because it enables researchers to discover non-annotated transcripts, single nucleotide variations (SNVs), splice variants, novel splice junctions and gene fusion events (Sultan et al., 2008; Trapnell et al., 2009; Edgren et al., 2011; Djebali et al., 2012; Quinn et al., 2013). Moreover, deep RNA-seq has greater specificity and sensitivity enabling detection of low expression and rare transcripts as well as cell- and tissue-specific lncRNAs (Wang et al., 2014; Liu et al., 2015; Li et al., 2016). Thus, an important parameter of RNA-seq for accurate quantification is read depth. For RNAs of moderate abundance, $\sim 30-40$ million reads are needed whereas for higher coverage (e.g., detecting rare and lowly expressed transcripts), reads of up to 500 million are recommended (Fu et al., 2014).

RNA-seq and next generation sequencing (NGS) has expanded significantly and over 400 methods have been established over the last decade (Hadfield and Retief, 2018). Emerging approaches include single-cell RNA-seq (scRNA-seq) which examines gene expression at a single-cell resolution, or assay for transposase-accessible chromatin sequencing (ATAC-seq) which locates regions of open chromatin, in genomic regions devoid of protein-coding genes. However, RNA-seq is not without its challenges. The analyses are more difficult and require more computational power; it is more costly; and multiple cycles of polymerase chain reaction (PCR) may introduce some amplification bias (Uchida, 2017). Importantly, lncRNA discovery is limited by annotations and genome build accuracy.

LncRNAs are difficult to annotate because of their low expression levels, our limited understanding of their sequencefunction relationship and their lack of evolutionary conservation. Thus, IncRNAs are currently annotated primarily based on transcriptomic evidence (Uszczynska-Ratajczak et al., 2018). The 2 main annotation approaches are automated or manual. With manual annotation, humans strategically put together transcriptomic and genomic data to build models that can create relatively accurate annotations. Automated annotation uses transcriptome assembly approaches that are quick and not costly, but typically result in incomplete and inaccurate annotations. To date, manual annotations are more accurate. Moreover, manual annotations have a higher quality assessment of lncRNA coding potential (via mass spectrometry, PhyloCSF, UniProt, and Pfam) (Sonnhammer et al., 1998; Apweiler et al., 2004; Lin et al., 2011). The most widely used manual annotation is GENCODE, followed by Reference Sequence (Refseq) (Harrow et al., 2012; Pruitt et al., 2014; Fang et al., 2018). There has been a historical bias toward using cell lines, adult tissues and tumor samples to build these reference databases. LncRNAs specifically expressed in rare cell populations, in response to various environmental stimuli, and in development may be excluded from these annotations. As technologies continue to advance, we predict that these databases will become more comprehensive with higher confidence lncRNA annotations.

\section{How to Study IncRNAs}

In order to study lncRNAs and their epigenetic and nonepigenetic functions, an arsenal of molecular biology techniques are employed by scientists. In Table 2 , we outline the most commonly used methodologies to study lncRNA-chromatin and lncRNA-protein interactions. To identify chromatin associated lncRNAs, approaches have been broadly classified into either "one-to-many" or "all-to-all." One-to-many approaches include

TABLE 1 | Methods to detect a IncRNA.

\begin{tabular}{llll}
\hline Method & Function & Advantages & Disadvantages \\
\hline Microarrays & To detect RNAs & $\begin{array}{l}\text { High throughput; } \\
\text { computationally manageable }\end{array}$ & $\begin{array}{l}\text { Background noise from } \\
\text { cross-hybridizations or weak binding }\end{array}$ \\
RNA sequencing & To detect RNAs & $\begin{array}{l}\text { Able to detect new transcripts; } \\
\text { high sensitivity with increased } \\
\text { read depth }\end{array}$ & $\begin{array}{l}\text { LncRNA discovery limited by } \\
\text { annotations and genome build } \\
\text { accuracy }\end{array}$
\end{tabular}


TABLE 2 | Methods to study IncRNA function.

\begin{tabular}{|c|c|c|c|c|c|}
\hline Method & Function & Advantages & Disadvantages & LncRNA example & $\begin{array}{c}\text { Method } \\
\text { Reference }\end{array}$ \\
\hline $\begin{array}{l}\text { Chromatin Isolation } \\
\text { by RNA purification } \\
\text { (ChIRP) }\end{array}$ & $\begin{array}{l}\text { To identify } \\
\text { IncRNA-chromatin } \\
\text { interactions }\end{array}$ & $\begin{array}{l}\text { Probes can be designed } \\
\text { without knowledge of } \\
\text { structure or functional } \\
\text { domains of target IncRNA }\end{array}$ & $\begin{array}{l}\text { Background noise from } \\
\text { non-specific binding }\end{array}$ & $\begin{array}{l}\text { MEG3, HOTAIR (Chu } \\
\text { et al., 2011; lyer et al., } \\
\text { 2017) }\end{array}$ & Chu et al., 2011 \\
\hline $\begin{array}{l}\text { Capture hybridization } \\
\text { analysis of RNA } \\
\text { targets (CHART) }\end{array}$ & $\begin{array}{l}\text { To identify } \\
\text { IncRNA-chromatin } \\
\text { interactions }\end{array}$ & $\begin{array}{l}\text { Probes can be designed } \\
\text { without knowledge of } \\
\text { structure or functional } \\
\text { domains of target IncRNA }\end{array}$ & $\begin{array}{l}\text { Background noise from } \\
\text { non-specific binding }\end{array}$ & $\begin{array}{l}\text { NEAT1, MALAT1 (West } \\
\text { et al., 2014) }\end{array}$ & Simon et al., 2011 \\
\hline $\begin{array}{l}\text { RNA antisense } \\
\text { purification (RAP) }\end{array}$ & $\begin{array}{l}\text { To identify } \\
\text { IncRNA-chromatin } \\
\text { interactions }\end{array}$ & $\begin{array}{l}\text { Longer probes mitigate } \\
\text { background noise }\end{array}$ & $\begin{array}{l}\text { Need probes to overlap } \\
\text { entire length of IncRNA for } \\
\text { capture }\end{array}$ & $\begin{array}{l}\text { XIST, FIRRE (Engreitz } \\
\text { et al., 2013; } \\
\text { Hacisuleyman et al., } \\
\text { 2014) }\end{array}$ & Engreitz et al., 2013 \\
\hline $\begin{array}{l}\text { Mapping } \\
\text { RNA-genome } \\
\text { interactions (MARGI) }\end{array}$ & $\begin{array}{l}\text { To identify } \\
\text { IncRNA-chromatin } \\
\text { interactions }\end{array}$ & $\begin{array}{l}\text { Identifies native } \\
\text { RNA-chromatin interactions } \\
\text { in vivo and in vitro }\end{array}$ & $\begin{array}{l}\text { Moderate sensitivity might } \\
\text { decrease detection of low } \\
\text { abundance } \\
\text { chromatin-associated } \\
\text { RNAs }\end{array}$ & $\begin{array}{l}\text { XIST, SNHG1, NEAT1, } \\
\text { MALAT1 (Sridhar et al., } \\
\text { 2017) }\end{array}$ & Sridhar et al., 2017 \\
\hline $\begin{array}{l}\text { Global RNA } \\
\text { interaction with DNA } \\
\text { sequencing } \\
\text { (GRID-seq) }\end{array}$ & $\begin{array}{l}\text { To identify } \\
\text { IncRNA-chromatin } \\
\text { interactions }\end{array}$ & $\begin{array}{l}\text { Identifies genome-wide } \\
\text { IncRNA-chromatin } \\
\text { interactions in situ }\end{array}$ & $\begin{array}{l}\text { Moderate sensitivity might } \\
\text { decrease detection of low } \\
\text { abundance } \\
\text { chromatin-associated } \\
\text { RNAs }\end{array}$ & $\begin{array}{l}\text { MALAT1, NEAT1 (Li X. } \\
\text { et al., 2017) }\end{array}$ & Li X. et al., 2017 \\
\hline $\begin{array}{l}\text { Chromatin- } \\
\text { associated RNA } \\
\text { sequencing } \\
\text { (ChAR-seq) }\end{array}$ & $\begin{array}{l}\text { To identify } \\
\text { IncRNA-chromatin } \\
\text { interactions }\end{array}$ & $\begin{array}{l}\text { Identifies genome-wide } \\
\text { IncRNA-chromatin } \\
\text { interactions in situ }\end{array}$ & $\begin{array}{l}\text { Moderate sensitivity might } \\
\text { decrease detection of low } \\
\text { abundance } \\
\text { chromatin-associated } \\
\text { RNAs }\end{array}$ & $\begin{array}{l}\text { roX1 and roX2 in } \\
\text { Drosophila (Bell et al., } \\
\text { 2018) }\end{array}$ & Bell et al., 2018 \\
\hline $\begin{array}{l}\text { RNA and DNA } \\
\text { interacting } \\
\text { complexes ligated } \\
\text { and sequenced } \\
\text { (RADICL-seq) }\end{array}$ & $\begin{array}{l}\text { To identify } \\
\text { IncRNA-chromatin } \\
\text { interactions }\end{array}$ & $\begin{array}{l}\text { RNase } \mathrm{H} \text { and actinomycin } \\
\mathrm{D} \text { decrease bias for nascent } \\
\text { transcripts; improved } \\
\text { genomic coverage and } \\
\text { unique mapping efficiency }\end{array}$ & $\begin{array}{l}\text { Moderate sensitivity might } \\
\text { decrease detection of low } \\
\text { abundance } \\
\text { chromatin-associated } \\
\text { RNAs }\end{array}$ & $\begin{array}{l}\text { MALAT1 (Bonetti et al., } \\
\text { 2020) }\end{array}$ & Bonetti et al., 2020 \\
\hline $\begin{array}{l}\text { Chromosome } \\
\text { conformation capture } \\
\text { (3C) }\end{array}$ & $\begin{array}{l}\text { Characterizing spatial } \\
\text { topology of long-range } \\
\text { DNA interactions }\end{array}$ & $\begin{array}{l}\text { High throughput; many } \\
\text { variations have emerged }\end{array}$ & $\begin{array}{l}\text { Risk of artifacts during data } \\
\text { analysis }\end{array}$ & $\begin{array}{l}\text { ANRIL (Nakaoka et al., } \\
\text { 2016) }\end{array}$ & $\begin{array}{l}\text { Dekker et al., } \\
\text { 2002a; } \\
\text { Lieberman-Aiden } \\
\text { et al., 2009; Han } \\
\text { et al., 2018 }\end{array}$ \\
\hline $\begin{array}{l}\text { RNA } \\
\text { Immunoprecipitation } \\
\text { (RIP) }\end{array}$ & $\begin{array}{l}\text { Identifies IncRNA-protein } \\
\text { interactions }\end{array}$ & $\begin{array}{l}\text { Sensitive and specific for } \\
\text { RNA detection }\end{array}$ & $\begin{array}{l}\text { Need specific antibodies for } \\
\text { protein targets }\end{array}$ & $\begin{array}{l}\text { HOTTIP (Hu et al., } \\
\text { 2019) }\end{array}$ & $\begin{array}{l}\text { Lerner and Steitz, } \\
\text { 1979; Ule et al., } \\
2018\end{array}$ \\
\hline $\begin{array}{l}\text { Cross-linking and } \\
\text { immunoprecipitation } \\
(\mathrm{CLIP})\end{array}$ & $\begin{array}{l}\text { Identifies IncRNA-protein } \\
\text { interactions }\end{array}$ & $\begin{array}{l}\text { No nucleases used; do not } \\
\text { need special } \\
\text { reagents/equipment }\end{array}$ & $\begin{array}{l}\text { UV light can cause } \\
\text { mutations; low sensitivity }\end{array}$ & $\begin{array}{l}\text { NEAT1 (Wen et al., } \\
\text { 2020) }\end{array}$ & Ule et al., 2003 \\
\hline RNA pull-down & $\begin{array}{l}\text { Identifies IncRNA-protein } \\
\text { interactions }\end{array}$ & $\begin{array}{l}\text { Improved discovery of } \\
\text { weak/transient binding }\end{array}$ & $\begin{array}{l}\text { Artificially increasing } \\
\text { IncRNA of interest may } \\
\text { generate false positives }\end{array}$ & $\begin{array}{l}\text { STEEL (Man et al., } \\
\text { 2018) }\end{array}$ & $\begin{array}{l}\text { Marín-Béjar and } \\
\text { Huarte, } 2015\end{array}$ \\
\hline $\begin{array}{l}\text { Chromatin } \\
\text { immunoprecipitation } \\
(\mathrm{ChIP})\end{array}$ & $\begin{array}{l}\text { Identifies proteins } \\
\text { associated with specific } \\
\text { genomic regions }\end{array}$ & $\begin{array}{l}\text { Can identify histone } \\
\text { proteins and histones with } \\
\text { modifications (e.g., } \\
\text { methylation, acetylation) }\end{array}$ & Need specific antibodies & $\begin{array}{l}\text { HOTTIP and ANRIL } \\
\text { (Nakaoka et al., 2016; } \\
\text { Hu et al., 2019) }\end{array}$ & $\begin{array}{l}\text { Massie and Mills, } \\
\text { 2012; Xie et al., } \\
2016\end{array}$ \\
\hline $\begin{array}{l}\text { RNA fluorescence } \\
\text { in situ hybridization } \\
\text { (RNA FISH) }\end{array}$ & $\begin{array}{l}\text { Visualization of subcellular } \\
\text { localization of IncRNA }\end{array}$ & $\begin{array}{l}\text { Branched chain } \\
\text { approaches can detect low } \\
\text { abundance IncRNAs with } \\
\text { single-cell resolution }\end{array}$ & Hybridization artifacts & $\begin{array}{l}\text { MEG3 (Cabili et al., } \\
\text { 2015) }\end{array}$ & $\begin{array}{l}\text { Gall and Pardue, } \\
1969\end{array}$ \\
\hline $\begin{array}{l}\text { RNA interference } \\
\text { (e.g., siRNA, shRNA) }\end{array}$ & $\begin{array}{l}\text { Guilt by association defined } \\
\text { by IncRNA knockdown }\end{array}$ & High knockdown efficiency & $\begin{array}{l}\text { Potential off-target effects } \\
\text { could lead to decreased } \\
\text { specificity; transfection } \\
\text { method artifacts }\end{array}$ & $\begin{array}{l}\text { STEEL (Man et al., } \\
\text { 2018) }\end{array}$ & $\begin{array}{l}\text { Dorsett and Tuschl, } \\
\text { 2004; Taxman } \\
\text { et al., } 2006\end{array}$ \\
\hline $\begin{array}{l}\text { Antisense } \\
\text { oligonucleotides } \\
\text { (ASOs) }\end{array}$ & $\begin{array}{l}\text { To silence IncRNA in order } \\
\text { to assess function }\end{array}$ & $\begin{array}{l}\text { Ideal for targeting } \\
\text { non-coding nuclear RNAs }\end{array}$ & $\begin{array}{l}\text { Potential off-target effects } \\
\text { could lead to decreased } \\
\text { specificity }\end{array}$ & $\begin{array}{l}\text { MALAT1 (Gong et al., } \\
\text { 2019) }\end{array}$ & Crooke, 2017 \\
\hline $\begin{array}{l}\text { Clustered regularly } \\
\text { interspersed short } \\
\text { palindromic Repeats } \\
\text { (CRISPR) }\end{array}$ & Ablate native IncRNA locus & $\begin{array}{l}\text { Can edit any regulatory } \\
\text { element (e.g., enhancer, } \\
\text { promoter, etc.); no mediator } \\
\text { machinery involved }\end{array}$ & $\begin{array}{l}\text { Need to have } \\
\text { "CRISPRable" genomic } \\
\text { locus; challenge to study } \\
\text { primary human cell types }\end{array}$ & $\begin{array}{l}\text { MANTIS, PRANCR } \\
\text { (Leisegang et al., 2017; } \\
\text { Cai et al., 2020) }\end{array}$ & Jinek et al., 2012 \\
\hline
\end{tabular}


chromatin isolation by RNA purification (ChIRP), capture hybridization analysis of RNA targets (CHART) and RNA antisense purification (RAP) (Chu et al., 2011; Simon et al., 2011; Engreitz et al., 2013). These methods are based on hybridizations of biotin-labeled probes targeted to lncRNAs of interest, followed by pull-down of the associated chromatin fraction. These techniques are limited by background noise from non-specific binding. RAP has relatively less background noise due to the use of longer probes, but these capture approaches could all be improved with further background corrections ( $\mathrm{Li}$ and Fu, 2019). ChIRP, CHART, and RAP can be combined with other techniques to discover more interactions within a single experiment. One example is domain-specific ChIRP (dsChIRP), a method by which lncRNAs domain-by-domain are assessed to identify functional elements (Quinn et al., 2014). Deep sequencing and/or mass spectrometry can be also be combined to obtain more high-resolution data on lncRNA interactions.

All-to-all approaches enable global detection of RNAchromatin interactions across all RNAs. These methods include mapping RNA-genome interactions (MARGI), global RNA interaction with DNA sequencing (GRID-seq), and chromatinassociated RNA sequencing (ChAR-seq) (Li X. et al., 2017; Sridhar et al., 2017; Bell et al., 2018). More recently, RADICL-seq (RNA and DNA interacting complexes ligated and sequenced) was developed (Bonetti et al., 2020). These techniques are based on a bivalent linker in which one end ligates to an RNA and the other end ligates to a restriction-digested DNA. Specifically, MARGI maps chromatin-RNA interactions through ligation of a lncRNA to its target genomic sequences, generating RNADNA chimeric sequences prior to sequencing. GRID-seq and ChAR-seq are very similar but GRID-seq employs a linker with 2 restriction sites for a type IIS restriction enzyme, MmeI, followed by digestion to produce size-specific products. On the other hand, ChAR-seq employs sonication of ligated products to generate smaller fragments prior to library preparation. RADICL-seq is similar to GRID-seq in that its linker also has 2 restriction sites (for EcoP15I), but it also uniquely employs RNase $\mathrm{H}$ and actinomycin $\mathrm{D}$ to reduce bias toward abundant nascent transcripts. These all-to-all methods are limited by their moderate sensitivity, which could decrease the detection of low abundance chromatin-associated RNAs.

To visualize $3 \mathrm{D}$ chromatin interactions, chromosome conformation capture (3C) has historically been used to characterize long-range DNA contacts (Dekker et al., 2002a; Han et al., 2018). Many adaptations of this technique exist, including chromosome conformation capture-on-chip (4C), or chromosome conformation capture carbon copy (5C). These variations require knowledge of the target loci, but another adaptation referred to as $\mathrm{Hi}-\mathrm{C}$, provides unbiased locations of chromatin interactions across the genome (Lieberman-Aiden et al., 2009).

To study lncRNA-protein interactions, scientists utilize RNA immunoprecipitation (RIP), cross-linking and immunoprecipitation (CLIP), and RNA pull-down (Lerner and Steitz, 1979; Ule et al., 2003, 2018; Marín-Béjar and Huarte, 2015). Another immunoprecipitation-based approach is chromatin immunoprecipitation (ChIP) which identifies protein-DNA interactions (Massie and Mills, 2012; Xie et al., 2016). These techniques have further advanced in recent years. For example, RIP can be combined with APEX (engineered ascorbate peroxidase)-catalyzed proximity biotinylation of endogenous proteins (APEX-RIP) to improve the spatial resolution of RNA mapping (Kaewsapsak et al., 2017). A recent study used APEX-RIP to generate a transcriptome-wide RNA atlas (Fazal et al., 2019).

Another powerful technique is RNA fluorescence in situ hybridization (FISH) which allows researchers to visualize RNA and DNA molecules while retaining cell morphology (Gall and Pardue, 1969; Collins et al., 1997; Cabili et al., 2015). The quantitative strength of this assay has increased with improvements of the branched DNA signal amplification technology to amplify the signal 1,000-10,000-fold. FISH improves the detection of lowly expressed lncRNAs. Recently, fluorescence in situ RNA sequencing (FISSEQ) was developed (Lee et al., 2015). FISSEQ provides high throughput information on tissue-specific gene expression while maintaining spatial context.

To silence lncRNAs and study their functions, there are many well-established techniques. There is RNA interference (RNAi), which is widely used, and is very efficient at knocking down RNAs (Watts and Corey, 2012; Chery, 2016). RNAi works best at targeting cytoplasmic lncRNAs. To silence nuclear lncRNAs, antisense oligonucleotides (ASOs) can be used in which RNase $\mathrm{H}$ is recruited to hydrolyze RNA in a DNA: RNA complex, causing transcriptional silencing of the target lncRNA. Finally, there is clustered regularly interspaced short palindromic repeats (CRISPR) which is similar to RNAi except that it is not reliant on mediator machinery (Jinek et al., 2012; Awwad, 2019). CRISPR can directly target genomic regions, allowing scientists to target regulatory regions like promoters or enhancers. CRISPR interference (CRISPRi) has been used for large-scale, systematic lncRNA screens in cell lines, demonstrating how this tool can be used to identify lncRNAs and further study their functions (Koch, 2017; Liu et al., 2017, 2020; Cai et al., 2020). Importantly, not all lncRNAs can be studied using CRISPR because CRISPR efficiency is affected by internal or bidirectional promoters (Goyal et al., 2017).

LncRNAs are a highly heterogeneous and functionally diverse class of molecules. As we illustrate in this section, there is a growing number of methods that enable functional characterization of lncRNAs. Many of these methods can be combined to efficiently map the lncRNA interactome. The data generated are increasingly being archived on a multitude of public databases. We direct readers to reviews that outline existing lncRNA databases (Peng et al., 2020; Pinkney et al., 2020). There is no doubt that high-throughput technologies will continue to advance to produce higher quality lncRNA data and improve our overall understanding of their molecular functions.

\section{ANGIOGENESIS}

The de novo formation of blood vessels from angioblasts and circulating hematopoietic stem cells is called vasculogenesis (Cines et al., 1998). In the absence of healthy vascular 
development, embryonic lethality results. Post-natally, new blood vessels form from pre-existing blood vessels in a closed cardiovascular system in a process called angiogenesis. Angiogenesis plays an important role in development, wound healing, and many other physiological processes (Schmidt and Carmeliet, 2010). ECs are instrumental in the orchestration of angiogenesis. It is a highly choreographed cascade of events that involves both exogeneous (e.g., hypoxia and VEGF) and endogenous regulatory inputs. There are two main types of angiogenesis: sprouting angiogenesis and intussusceptive angiogenesis. In sprouting angiogenesis, as the name suggests, new blood vessels grow via "sprout" formation from existing vessels through EC proliferation and migration (Ackermann et al., 2014). In contrast, intussusceptive angiogenesis, also referred to as splitting angiogenesis, there is little dependence on EC proliferation and migration. Instead, the ECs reorganize, and the cells invade the lumen forcing the vessel to split (Konerding et al., 2012). Both forms of angiogenesis, which are believed to occur in nearly all organs and tissues, produce new vasculature, most often in capillary beds (Adair and Montani, 2010). Sprouting angiogenesis, hereafter angiogenesis, is better understood and the most well-studied. As such, it will be the focus of this review.

A multitude of factors work together in a dynamic network to maintain tight regulation of angiogenesis. This is to prevent insufficient or over-vascularization from occurring. A major environmental regulator is hypoxia, which can be defined as an imbalance between oxygen supply and demand. The main intracellular signaling molecule is hypoxia inducible factor (HIF), a transcription factor comprised of HIF-alpha and HIFbeta subunits (Shweiki et al., 1992). The HIF-alpha subunit is functionally regulated by oxygen-dependent post-translational modifications of prolyl residues. In normoxia, the prolyls are hydroxylated, and Von Hippel-Lindau (VHL) recruits the E3 ubiquitin ligase complex to ubiquitinate the HIF-alpha subunits and make them a target for proteasomal degradation (Chen et al., 2009). In contrast, in hypoxic conditions, there is no hydroxylation and therefore no subsequent ubiquitination. Thus, HIF is not degraded and instead accumulates and translocates to the nucleus. Together with the constitutively expressed HIF-beta, it can bind to the hypoxia-responsive cis-DNA element (HRE) and modify transcription of a number of genes, many of which are involved in angiogenesis. This includes genes like matrix metalloproteinase-2 (MMP-2), angiopoietin-2 (Ang-2), Tie-2, PDGF, Delta-like 4 (DLL4) and many more factors. However, the most important target is arguably vascular endothelial growth factor (VEGF). The development of normal vasculature is heavily dependent on a VEGF gradient (see Figure 2). When the gene dose of VEGF is reduced by $50 \%$, it causes embryonic lethality due to vascular deficiencies (Carmeliet et al., 1996; Ferrara et al., 1996). Conversely, overexpression of VEGF, as seen in tumors, causes exuberant EC activation, leading to a disorganized

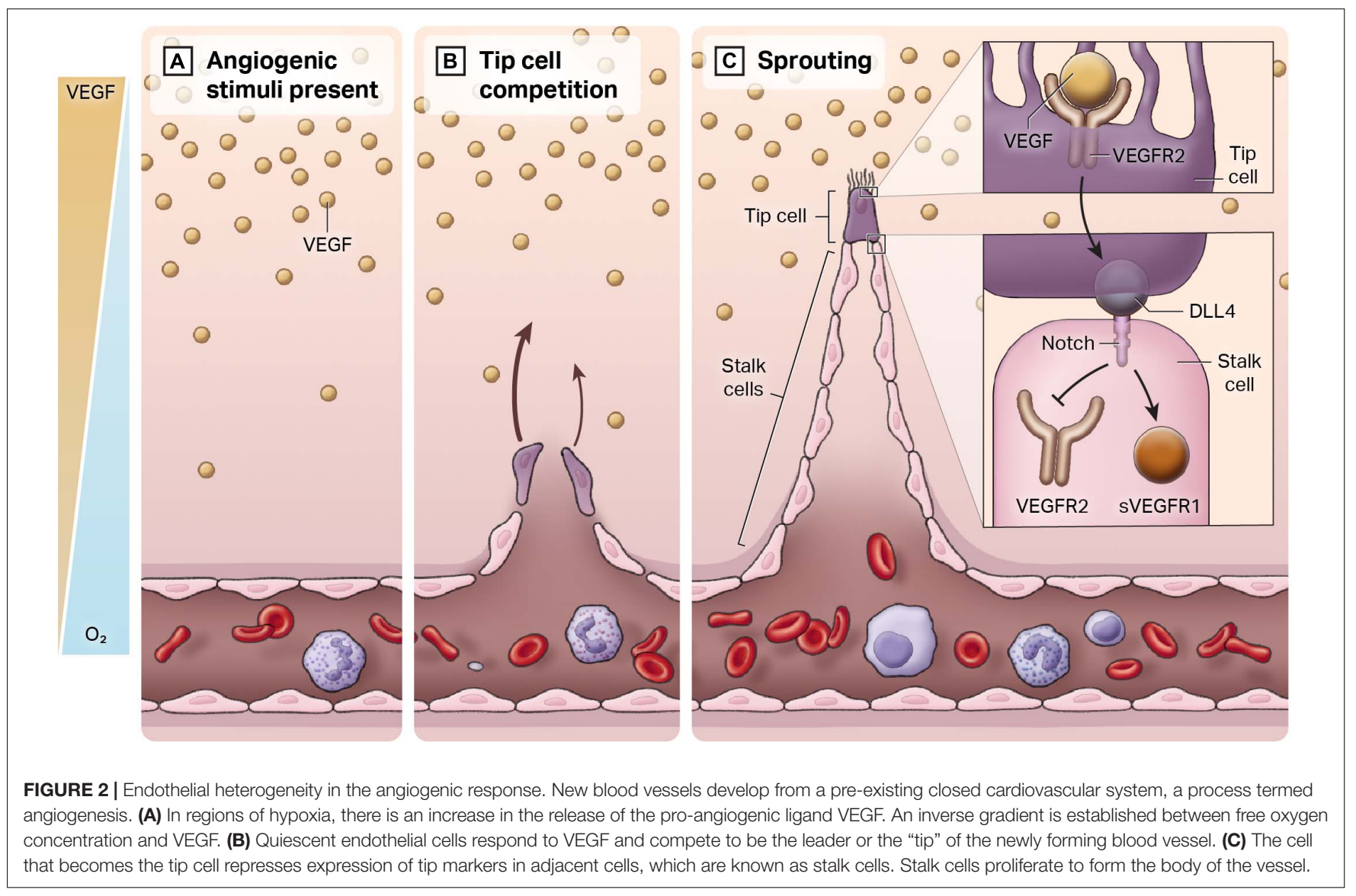


vasculature (Jain, 2005). Since VEGF is a potent regulator of angiogenesis, VEGF is often targeted therapeutically to treat diseases in which this process is dysregulated.

In healthy adult blood vessels, vascular ECs exhibit a low rate of cell number turnover (Sender and Milo, 2021). Adult humans exhibit approximately 1 trillion ECs, with a mean life span typically of 3-10 years. This long-life span can be contrasted with red blood cells or circulating white blood cells, which approximate 120 and 7 days, respectively. Importantly, the basal low rate of turnover of ECs can be markedly augmented. Our current understanding of angiogenesis can be encapsulated by the tip-stalk paradigm (see Figure 2). Once hypoxia has helped establish the VEGF gradient from non-endothelial cell types (e.g., macrophages), ECs respond and begin to migrate toward this angiogenic stimulus. These ECs are called "tip cells," and they are morphologically characterized by filopodia and stress fibers, which facilitate invasion into the surrounding tissue and creates a clear path for sprouting to commence (Eilken and Adams, 2010). VEGF binds to vascular endothelial growth factor receptor 2 (VEGFR2) receptors in tip cells, activating DLL4, which then binds to Notch receptors in adjacent ECs (Adams and Alitalo, 2007). Notch signaling is activated in adjacent ECs and suppresses tip genes, such as VEGFR2 and DLL4, to prevent these ECs from also becoming tip cells. These cells are referred to as "stalk cells." In addition to positional identity, stalk cells are highly proliferative, lack filopodia and contribute to lumen formation. They express soluble VEGFR1 (sVEGFR1), which sequesters VEGF-A in a regulatory manner to prevent VEGF-induced signaling (del Toro et al., 2010).

Once multiple sprouts have formed, tip cells of different sprouts will anastomose with each other, which is believed to occur through filopodial interactions (Bentley et al., 2009). This creates vessel networks. Wnt signaling is also important in angiogenesis. Specifically, the interplay between Notch signaling and Wnt signaling causes an upregulation of $\beta$-catenin expression. $\beta$-catenin is important in stabilizing tight junctions and activating PDGF-B expression. PDGF-B promotes recruitment of mural cells/support cells, which is an indicator of healthy and mature vessels and prevents vessel "leakiness" (Gavard and Gutkind, 2008; Reis et al., 2012). Lumenization and blood flow will further stabilize these new vessel connections (Chappell et al., 2011; Potente et al., 2011). Once the vessels have been perfused, the ECs will move toward a quiescent phenotype. It is important to note that the underlying mechanisms, in particular of these final phases of sprouting angiogenesis, are not well understood.

As inferred from above, hemodynamic forces must regulate angiogenesis. In regions of the body in which angiogenesis occurs such as in muscle that undergoes remodeling following exercise, there are markedly increased levels of shear stress. In contrast, there is low shear stress in a tumor. Of note, angiogenesis occurs at both these levels of shear stress, though in opposite directions (Kaunas et al., 2011). In normal physiological conditions, shear stress varies depending on the vessel type. In arteries, shear stress can range between 10 and 70 dynes $/ \mathrm{cm}^{2}$, whereas in veins, shear stress can range between 1 and 6 dynes $/ \mathrm{cm}^{2}$ (Lipowsky, 1995; Malek, 1999). Thus, it is not the absolute value of shear stress that induces angiogenesis, but instead, the deviation from normal levels detected by the ECs that stimulates this physiological response.

\section{NUCLEAR ENDOTHELIAL-ENRICHED ANGIOGENIC IncRNAs}

In the last several years, lncRNAs that regulate biological processes like angiogenesis have emerged. In this section, we will highlight angiogenic lncRNAs that act through chromatin-based mechanisms to effect angiogenesis, including STEEL, GATA6-AS, and MANTIS (Table 3). These lncRNAs are also of particular interest because they are regulated by environmental stimuli that regulate angiogenesis: hemodynamic forces and hypoxia.

\section{STEEL}

STEEL was the first flow-regulated, endothelial-enriched lncRNA identified. STEEL is a pro-angiogenic lncRNA that links decreased laminar shear stress with pro-angiogenic programming. It is downregulated by laminar flow (10 dynes $/ \mathrm{cm}^{2}$ ) and enriched in microvascular ECs (Man et al., 2018). In static conditions, STEEL maintains eNOS and KLF2 expression at basal levels required for angiogenesis. Consistent with its nuclear localization, we found evidence that STEEL regulates eNOS and KLF2 by transcriptional mechanisms. First, STEEL knockdown decreased heterogeneous nuclear RNA (hnRNA) levels and decreased RNA polymerase II (Pol II) loading at the proximal promoters of eNOS and KLF2. Moreover, STEEL regulates chromatin accessibility, nucleosome occupancy and histone 3 lysine 4 trimethylation (H3K4me3) at both eNOS and KLF2 proximal promoters. Interestingly, a feedback loop exists in which laminar shear stress $\left(10\right.$ dynes $\left./ \mathrm{cm}^{2}\right)$ induces high levels of eNOS and KLF2, which in turn represses STEEL expression. In this way, STEEL functions as a rheostat of angiogenesis that responds to shear stress conditions. Mechanistically, they identified a lncRNA-protein interaction that presents a new mechanism for genomic targeting of the polyADP ribosylase 1 (PARP1), which contributes to transcriptional regulation, DNA damage repair, and cardiovascular disease (Chaudhuri and Nussenzweig, 2017). Using RNA pulldown followed by mass spectrometry and RIP to identify and confirm this interaction, respectively, and ChIP to demonstrate an effect of STEEL knockdown on PARP1 occupancy at the eNOS and KLF2 promoters. Together, these mechanistic studies of the STEEL lncRNA provide evidence for epigenetic regulation of gene expression and novel lncRNA-protein interactions. The underlying mechanisms of these interactions require further investigation.

Regarding its angiogenic functions, STEEL was shown to affect blood vessel formation both in vitro and in vivo. Using a Matrigel network assay in HUVEC, STEEL knockdown decreased network formation while STEEL overexpression increased network formation (Man et al., 2018). Cell migration is characteristic of tip cells and cell proliferation is characteristic of stalk cells. Both assessments are key measures of sprouting angiogenesis and were therefore examined. As expected, through scratch wound assay, carboxyfluorescein 
TABLE 3 | Summary of endothelial-enriched angiogenic IncRNA function.

\begin{tabular}{|c|c|c|c|}
\hline LncRNA & Epigenetic mechanism of action & Function in angiogenesis & References \\
\hline STEEL & $\begin{array}{l}\text { In static conditions, STEEL is recruited to EC proximal promoter } \\
\text { regions, eNOS and KLF2, where STEEL's association will } \\
\text { enhance transcription. }\end{array}$ & $\begin{array}{l}\text { STEEL increases angiogenesis in vitro } \\
\text { and in vivo. }\end{array}$ & Man et al., 2018 \\
\hline GATA6-AS & $\begin{array}{l}\text { Hypoxia-responsive GATA6-AS interacts with LOXL2 and } \\
\text { deactivates H3K } 4 \text { me3 to repress transcription of COX-2 and } \\
\text { POSTN. }\end{array}$ & $\begin{array}{l}\text { GATA6-AS increases sprouting in vitro } \\
\text { but decreases blood vessel formation } \\
\text { in vivo. }\end{array}$ & $\begin{array}{c}\text { Neumann et al., } \\
2018\end{array}$ \\
\hline MANTIS & $\begin{array}{l}\text { When JARID1B is repressed, MANTIS increases and associates } \\
\text { with BRG1, which is associated with the SWI/SNF remodeling } \\
\text { complex and is stabilized by BAF155. }\end{array}$ & $\begin{array}{l}\text { MANTIS increases transcription of } \\
\text { pro-angiogenic factors (i.e., COUP-TFII, } \\
\text { SMAD6, SOX18) in vitro. }\end{array}$ & $\begin{array}{l}\text { Leisegang et al., } \\
\text { 2017, } 2019\end{array}$ \\
\hline
\end{tabular}

succinimidyl ester (CFSE) labeling and bromodeoxyuridine (BrdU) incorporation, STEEL overexpression promoted EC proliferation and migration. These results were confirmed in vivo using a mouse model. Collagen modules with stromal cells were coated with either control or STEEL overexpressing ECs transduced and implanted into immunocompromised mice. Using micro-computed tomography (micro-CT) imaging, it was found that STEEL-transduced implants had more vessels that were perfused compared to control implants, which not only had fewer vessels, but also demonstrated extravasation and pooling. Further examination of the STEELtransduced implants' vascular networks revealed that the blood vessels showed mural cell support, as indicated by smooth muscle actin staining, demonstrating vessel maturity. Of note, STEEL-induced angiogenesis did not display evidence of morphologically abnormal vessels (e.g., contrast leakage, lack of pericyte coverage).

\section{GATA6-AS}

Another endothelial-enriched lncRNA is the antisense transcript of GATA6 (GATA6-AS). GATA6-AS is upregulated approximately 2.5 -fold under chronic hypoxia $(24 \mathrm{~h})$ and localized primarily to the nucleus (Neumann et al., 2018). Using mass spectrometry, it was found that GATA6-AS interacts with lysyl oxidase-like 2 (LOXL2), a known hypoxia regulator (Bignon et al., 2011). Nuclear LOXL2 is a known co-repressor of transcriptional activity and deactivates $\mathrm{H} 3 \mathrm{~K} 4 \mathrm{me} 3$. With GATA6-AS repression, there was a 30\% decrease in H3K4me3, which also occurred under hypoxia. Curiously, when LOXL2 was repressed, H3K4me3 was increased, and the majority of GATA6AS regulated genes were inversely expressed when compared to GATA6-AS repression. Cyclooxygenase-2 (COX-2) and periostin (POSTN) were more closely examined with ChIP-PCR. COX-2 catalyzes the production of prostaglandins in ECs, which contributes to flow-mediated vasodilation whereas POSTN acts through Erk/VEGF signaling to stimulate angiogenesis (Koller et al., 1993; Duffy et al., 1998). GATA6-AS silencing markedly decreased $\mathrm{H} 3 \mathrm{~K} 4 \mathrm{me} 3$ at the promoter regions of both these genes, pointing toward an epigenetic role for GATA6-AS on EC gene expression.

It was argued that GATA6-AS regulates angiogenesis through endothelial-to-mesenchymal transition (EndMT), a process that can be induced by hypoxia (Neumann et al., 2018). Using an EndMT-assay, repressing GATA6-AS in HUVECs largely inhibited EndMT. Further in vitro analysis of angiogenesis using a spheroid assay showed that GATA6-AS silencing significantly decreased sprouting. GATA6-AS repression decreased cell migration, but it did not affect proliferation or apoptosis. The effect GATA6-AS has on the EndMT process may in turn, be affecting angiogenic potential. Using an in vivo immune deficient mouse model, HUVEC transfected with control GapmeRs or GapmeRs against GATA6-AS were transplanted. Through histological visualization, GATA6-AS repressed cells had a marked increase in the number of perfused, mature blood vessels compared to controls. These in vivo findings are contradictory to the in vitro results. The decrease in sprouting in vitro may be compensated for through other mechanisms in vivo. LOXL2 in the extracellular matrix is also involved in angiogenesis. When LOXL2 was repressed, there was a decrease in sprouting. Interestingly, LOXL2 did not decrease with GATA6AS silencing. It is clear GATA6-AS is regulating angiogenesis, but the mechanisms require further study.

\section{MANTIS}

MANTIS is a flow-regulated lncRNA expressed by ECs. This nuclear lncRNA was identified through inhibition of an EC-enriched H3K4 lysine-specific demethylase 5B (JARID1B) (Leisegang et al., 2017). MANTIS is not specific to ECs; it is also expressed by smooth muscle cells. Steady, laminar flow upregulates MANTIS and is mediated through KLF2 and KLF4 (Leisegang et al., 2019). Moreover, when MANTIS was repressed, HUVEC were unable to align in the direction of flow. Using ChIP, JARID1B was bound to an $\mathrm{H} 3 \mathrm{~K} 4 \mathrm{me} 3$ region near the MANTIS transcription start site (TSS), which was further increased with JARID1B silencing. Using mass spectrometry, MANTIS was found to be highly associated with Brahma Related Gene 1 (BRG1), an ATPase involved in the SWItch/Sucrose Non-Fermentable (SWI/SNF) chromatin remodeling complex and important for EC function. BRG1 is stabilized by BAF155. With MANTIS silencing, there was marked reduction in BRG1 and BAF155 binding and the ability of BRG1 to bind to target promoters.

Using CRISPR/Cas9, MANTIS was functionally inactivated in HUVEC, resulting in significantly less tube formation and sprouting. Silencing MANTIS yielded similar results and also decreased cell migration. This also resulted in decreased mRNA and protein expression of factors important in angiogenesis including chicken ovalbumin upstream promoter - transcription 
factor 2 (COUP-TFII), SMAD6 and sex determining region Y-box 18 (SOX18). It should be noted that there are many other tip and stalk genes that are also relevant that were not assessed in this study. When these 3 factors are reduced, there is decreased sprouting and yet, overexpression of these factors does not restore sprouting to normal. However, the regulation of these proteins through MANTIS may be important in maintaining healthy sprouting in ECs. MANTIS was knocked down and ATAC-Seq was conducted. BRG1 protein levels were unchanged, but at the TSS of COUP-TFII, SMAD6 and SOX18, there was a decrease in open chromatin. Using micrococcal nuclease (MN) digestion, there was an increase in nucleosomal formation at the TSS of these 3 genes when MANTIS was decreased. MANTIS repression increased $\mathrm{H} 3 \mathrm{~K} 27 \mathrm{me} 3$, and decreased RNA Pol II at the TSS of all 3 genes. In addition, silencing MANTIS reduced BRG1 binding at the TSS of COUP-TFII, SMAD6 and SOX18. Since BRG1 is known to play a role in nucleosome remodeling, this may suggest that BRG1's interactions with these proteins may be mediated through MANTIS. Further study of MANTIS is needed to better understand these interactions.

\section{ANGIOGENIC IncRNAs IN DISEASE}

The majority of lncRNAs that have been identified and characterized have been in diseases. This include cancers (Jin et al., 2020; Teppan et al., 2020; Zhou et al., 2020; Katsushima et al., 2021), diabetes (Taheri et al., 2020; Xu E. et al., 2020; Ismail et al., 2021), cardiovascular diseases (Fang et al., 2020; Meng et al., 2020; Yeh et al., 2020) and ischemic stroke (Gan et al., 2021; Wolska et al., 2021). In this section, we will focus on angiogenic lncRNAs enriched in disease and their epigenetic functions. We will highlight some of the most extensively studied lncRNAs: MALAT1, MEG3 and ANRIL. A summary of these as well as other more recently published disease-associated angiogenic lncRNAs can be seen in Table 4 (Zhou et al., 2016; Li Y. et al., 2017; Ruan et al., 2018; Niu et al., 2020; Xu X. et al., 2020; Zhang H. et al., 2020; Biswas et al., 2021).

\section{MALAT1}

MALAT1, as the name suggests, is implicated in protean cancer cell types. It is extremely abundant in multiple cell types, including vascular ECs (Gutschner et al., 2013; Michalik et al., 2014; Yan et al., 2016). Primarily localized in the nucleus as part of nuclear speckles, MALAT1 associates with the serine/arginine (SR) family of pre-mRNA splicing factors such as SRSF1/2/3; it plays an important role in alternative splicing. When MALAT1 is silenced, it results in reduced nuclear speckle association of many pre-mRNA splicing factors including SF1, U2AF65, SF3a60, and U2snRNP in vitro (Tripathi et al., 2010). MALAT1 may have species-specific function. Unexpectedly, Malat1 knockout mice evidenced no change in nuclear speckle markers compared to wildtype mice (Nakagawa et al., 2012). This finding in mice was confirmed by other studies (Eißmann et al., 2012; Zhang et al., 2012).

MALAT1 also plays a critical role in transcriptional regulation, through direct binding to the $3^{\prime}$ end of actively transcribing gene bodies, and mediating localization of unmethylated proteins in nuclear speckles (Engreitz et al., 2014). MALAT1 functions as a molecular scaffold for unmethylated polycomb 2 proteins (PC2), E2F transcription factor, and histones involved in active transcription and the transcriptional coactivator complex (Yang et al., 2011). MALAT1 has a role in regulating expression of

TABLE 4 | Summary of disease-associated angiogenic IncRNA function.

\begin{tabular}{|c|c|c|c|c|}
\hline LncRNA & Disease & $\begin{array}{l}\text { Epigenetic mechanism of } \\
\text { action }\end{array}$ & Function in angiogenesis & References \\
\hline $\begin{array}{l}\text { HOX transcript antisense } \\
\text { RNA (HOTAIR) }\end{array}$ & Diabetic retinopathy & $\begin{array}{l}\text { Histone methylation, histone } \\
\text { acetylation, DNA methylation }\end{array}$ & $\begin{array}{l}\text { HOTAIR regulates glucose-mediated } \\
\text { increases of angiogenesis in diabetic } \\
\text { retinopathy }\end{array}$ & Biswas et al., 2021 \\
\hline $\begin{array}{l}\text { Small nucleolar RNA host } \\
\text { gene } 14 \text { (SNHG14) }\end{array}$ & Hepatocellular carcinoma & $\begin{array}{l}\text { SNHG14 upregulates PABPC1 } \\
\text { expression via H3K27 } \\
\text { acetylation }\end{array}$ & $\begin{array}{l}\text { SNHG14 promotes proliferation and } \\
\text { tube formation in endothelial cells }\end{array}$ & $\begin{array}{l}\text { Zhang H. et al., } \\
\qquad 2020\end{array}$ \\
\hline LINC00337 & Colorectal cancer & $\begin{array}{l}\text { LINC00337 recruits DNMT1 to } \\
\text { CNN1 promoter, which inhibits } \\
\text { its transcription and increases } \\
\text { VEGF-mediated angiogenesis }\end{array}$ & $\begin{array}{l}\text { LINC00337 increases tumor growth } \\
\text { and microvascular density }\end{array}$ & Xu X. et al., 2020 \\
\hline $\begin{array}{l}\text { RAB11B Antisense RNA } \\
1 \text { (RAB11B-AS1) }\end{array}$ & Breast cancer, osteosarcoma & $\begin{array}{l}\text { RAB11B-AS1 increases RNA } \\
\text { Pol II in hypoxia to upregulates } \\
\text { VEGFA and ANGPLT4 }\end{array}$ & $\begin{array}{l}\text { HIF2 induces RAB11B-AS1 which } \\
\text { increases angiogenic factors }\end{array}$ & Niu et al., 2020 \\
\hline $\begin{array}{l}\text { Metastasis associated } \\
\text { lung adenocarcinoma } \\
\text { transcript } 1 \text { (MALAT1) }\end{array}$ & Multiple cancers & $\begin{array}{l}\text { Formation of molecular } \\
\text { scaffolds, splicing and } \\
\text { regulating histones and } \\
\text { transcription factors }\end{array}$ & $\begin{array}{l}\text { MALAT1 increased proliferation, } \\
\text { sprouting and migration in ECs }\end{array}$ & Li Y. et al., 2017 \\
\hline $\begin{array}{l}\text { Maternally expressed } 3 \\
\text { (MEG3) }\end{array}$ & $\begin{array}{l}\text { Idiopathic pulmonary fibrosis, } \\
\text { cholestatic liver injury }\end{array}$ & $\begin{array}{l}\text { MEG3 interacts with JARID2 } \\
\text { which recruits PRC2 }\end{array}$ & $\begin{array}{l}\text { MEG3 regulates NOTCH and VEGF } \\
\text { pathways }\end{array}$ & Ruan et al., 2018 \\
\hline $\begin{array}{l}\text { Antisense non-coding } \\
\text { RNA in the INK4 locus } \\
\text { (ANRIL, CDKN2B, } \\
\text { CDKN2B-AS1) }\end{array}$ & $\begin{array}{l}\text { Coronary heart disease, } \\
\text { ischemic stroke, type } 2 \\
\text { diabetes, atherosclerosis }\end{array}$ & $\begin{array}{l}\text { Promoter methylation, } \\
\text { chromatin modifications, } \\
\text { alternative splicing and } \\
\text { post-transcriptional } \\
\text { modifications }\end{array}$ & $\begin{array}{l}\text { High glucose upregulates ANRIL in } \\
\text { retinal ECs and is involved in VEGF } \\
\text { regulation }\end{array}$ & Zhou et al., 2016 \\
\hline
\end{tabular}


cyclins and cell cycle kinases. Specifically, it regulates S-phase cyclins, p21 and p27Kip1 in mouse (Michalik et al., 2014). Overall, MALAT1's abundance in the cell, varied half-life and structural stability conferred by its $3^{\prime}$ end triple-helix structure, contributes to its functional stability and diversity.

In gastric cancer, MALAT1 promotes vascular mimicry and angiogenesis to establish tumorigenicity and metastasis ( $\mathrm{Li} \mathrm{Y}$. et al., 2017). When MALAT1 is repressed in HUVEC, ECs were no longer able to form vessels via the tube formation assay. Knockdown was also able to increase EC permeability. With hypoxia, MALAT1 is upregulated and enhances proliferation of ECs in vitro. In another study by Michalik et al., MALAT1 knockdown in ECs increased sprouting and migration, but decreased stalk cell proliferation via cell cycle inhibition. Examining a mouse knockout of Malat1, scientists found no affect in adults, but it reduced vascular proliferation and network formation in embryonic retina. In the hind limb ischemia model, Malat1 deficiency decreased neovascularization, capillary density and recovery of blood flow. In thyroid tumors, MALAT1 promotes Fibroblast Growth Factor 2 (FGF2) secretion from tumor-associated macrophages into the tumor microenvironment to mediate angiogenesis (Huang et al., 2017). Together, the role of MALAT1 in angiogenesis is conferred by its role in alternative splicing, molecular scaffold formation and binding to actively transcribed gene loci, in particular the cell cycle genes. Clearly, MALAT1's functions are diverse.

\section{MEG3}

Maternally expressed gene 3 (MEG3) is a nuclear and ECenriched lncRNA that exhibits multiple mRNA transcript variants (Zhang et al., 2010). It is also an imprinted gene (Michalik et al., 2014). Imprinting is an epigenetic phenomenon in which monoallelic silencing of some genes occurs in a parentof-origin specific manner (Autuoro et al., 2014). This process is thought to be regulated by lncRNAs, though the mechanisms have yet to be fully elucidated. MEG3 is encoded by the imprinted DLK1-DIO3 locus, and it was found that it interacts with Jumonji And AT-Rich Interaction Domain Containing 2 (JARID2), an important component of PRC2 in pluripotent stem cells (Kaneko et al., 2014). This interaction is needed in order to recruit and assemble PRC2 at a subset of pluripotent stem cell genes. This suggests that the interplay of these RNA-based interactions may participate in the epigenetic regulation of genes involved in the process of transitioning stem cell pluripotency to differentiation. MEG3's binding sites also have GA rich regions critical to guiding MEG3 to chromatin through the formation of RNA-DNA triplex structures (Mondal et al., 2015).

MEG3 was shown to be among the top 10 most abundant lncRNAs in HUVEC, strongly suggesting a clear biological role in ECs (Michalik et al., 2014). It also inhibits VEGF and Notch pathways, which we know are important signaling pathways in angiogenesis (Gordon et al., 2010). Adding to this, MEG3 expression is also upregulated by hypoxia. Ruan et al. overexpressed constitutive HIF-1alpha and found increased activity in the MEG3 promoter. Next, they examined chronic treatment $(24 \mathrm{~h})$ of pro-angiogenic growth factors like VEGF, bFGF and Transforming Growth Factor $\beta$ (TGF $\beta$ ). There was no effect on MEG3 expression, but there were still notable angiogenic effects. MEG3 knockdown markedly decreased VEGFR2 mRNA and protein expression in HUVEC, which then inhibited cell migration. Moreover, it impaired the ability of ECs to form tube-like structures and significantly decreased sprouting from spheroids in both normoxic and hypoxic conditions (Ruan et al., 2018). It also was found that genes of the TGF $\beta$ signaling pathway are direct targets of MEG3 and that MEG3 binds to distal regulatory sites of these genes. Thus, even though there was not a direct effect with pro-angiogenic factors, the downstream factors of these angiogenic pathways are still indirectly regulated by MEG3.

MEG3 can be characterized as a tumor suppressor important in cell cycle regulation and apoptosis ( $\mathrm{Li}$ et al., 2015). Long-range interaction between distal loops of MEG3 secondary structure forms a pseudoknot which allows MEG3 to upregulate p53 expression (Li et al., 2015; Uroda et al., 2019). MEG3 allelic loss of locus is associated with meningioma pathogenesis and progression (Zhang et al., 2010). Expression of MEG3 in human meningioma cell lines clearly shows marked suppression of tumor cell growth and activation of p53. MEG3 also regulates age-associated decline in endothelial function; MEG3 was significantly upregulated in senescent HUVEC (passages 16-18) compared to earlier HUVEC passages (3-4) (Boon et al., 2016; He et al., 2017; Wu et al., 2017). Scientists found that when Meg3 was repressed in HUVEC, age-mediated inhibition of sprouting was stopped, implying that Meg3 silencing could be a potential way to rescue age-associated impairments in angiogenic potential. In the brain, Meg3 null mice exhibit enhanced vascular density (Gordon et al., 2010). Examining this closer, Meg3 null mice, showed increased VEGFA, VEGFR1, DLL4, among other angiogenic genes. It was previously shown that $\mathrm{p} 53$ could bind to Sp1 sites in the VEGFA promoter to negatively regulate VEGFA transcription (Pal et al., 2001). Thus, loss of MEG3 may decrease p53 binding, thereby causing an increase in transcription of genes involved in VEGF signaling. Clearly, MEG3 has an important role as an angiogenic regulator.

\section{ANRIL}

ANRIL (also known as CDKN2B or CDKN2B-AS1) is located on chromosome 9p21. GWAS identified this disease-associated locus as a "protein gene desert" (Cheng et al., 2005; Iaconetti et al., 2013; Wahlestedt, 2013; Carninci et al., 2021). ANRIL is transcribed antisense to the INK4b-ARF-INK4a gene cluster (Derrien et al., 2012). Exons 13-19 of ANRIL overlapped with a high-risk haplotype associated with genetic predisposition to coronary artery disease (CAD) (Broadbent et al., 2008). A genetic association is also evident with ischemic stroke, aneurysms, and peripheral vascular diseases (Zeggini et al., 2007; Foroud et al., 2012; Kremer et al., 2015; Kong et al., 2016; Tan et al., 2019). ANRIL is especially enriched in vascular smooth muscle cells (VSMC) and mononuclear phagocytes within atherosclerotic plaques (The Encode Project Consortium, 2012; Zollbrecht et al., 2013; Bai et al., 2014; Nanda et al., 2016). ANRIL is a better genetic predictor of cardiovascular diseases than classical clinical measures such as blood pressure and dyslipidemia (Holdt et al., 2010).

ANRIL has at least 20 linear or circular isoforms associated with atherosclerosis (Burd et al., 2010; Hubberten et al., 2019). 
Though the mechanism(s) by which minor frequency alleles of ANRIL still predispose to disease remain to be fully elucidated, it is argued that ANRIL regulates this genomic region in cis whereby the risk allele leads to an increase in linear ANRIL, but reduced levels of circular ANRIL (Holdt and Teupser, 2018). Linear ANRIL may function as a scaffold for epigenetic protein complexes that stimulate pro-atherosclerotic cellular functions. ANRIL is highly enriched in the nucleus, playing an active role in chromatin modification (Zhou et al., 2016). It is regulated by promoter methylation, transcription factors, alternative splicing and post-transcriptional modifications. ANRIL interacts with PRC1 \& PRC2 to epigenetically repress neighboring genes such as CDKN2A and CDKN2B in cis. ANRIL and CDKN2A form a scaffold with $\mathrm{H} 3 \mathrm{~K} 27 \mathrm{me} 3$ with polycomb Chromobox $7^{\prime \prime}$ (CBX7); ANRIL with CDKN2B interact with PRC2 subunit SUZ12 (Yap et al., 2010). Trans activity of ANRIL through PRC1/2 represses distant genes that are dependent on the Alu elements found in ANRIL and in target gene promoters. ANRIL creates a scaffold for WD repeat-containing protein 5 (WDR5), a histone $\mathrm{H} 3 \mathrm{~K} 4$ presenter and histone deacetylase 3 (HDAC3) coordinating histone modification on target genes of vascular smooth muscle cell phenotypes (Zhang C. et al., 2020).

ANRIL has been shown to be upregulated in human retinal ECs stimulated by high glucose and diabetes. In diabetic retinopathy, ANRIL regulates VEGF through interactions with PRC2 components p300, miR200b, and enhancer of zeste homolog 2 (EZH2) (Thomas et al., 2017). Since VEGF is involved in stimulating vascular permeability, migration and proliferation of ECs, ANRIL upregulating VEGF contributes to promoting endothelial injury, which occurs via tumor necrosis factor-alpha $(\mathrm{TNF} \alpha)$ - nuclear factor kappa light-chain-enhancer of activated B cells (NFkB)-ANRIL/YY-IL6 signaling pathways (Zhou et al., 2016). Similarly, in a rat model with diabetes and cerebral infarction, overexpression of ANRIL increased VEGF expression, resulting in increased angiogenesis via NFkB signaling (Zhang et al., 2017). ANRIL also regulates Akt phosphorylation in ECs and scientists recently showed that in mice, ANRIL improves cardiac function and post-ischemic angiogenesis following myocardial infarction by upregulating angiogenesis through Akt activation (Huang et al., 2020). Finally, Zeng et al. recently showed that ANRIL levels were elevated in the serum of thrombosis patients relative to healthy patients (Zeng et al., 2019). To assess the effect of ANRIL on angiogenesis, they took Sprague Dawley rats and injected si-ANRIL and examined lumen formation. They found that there were fewer lumens and smaller lumens in the rats with repressed ANRIL relative to the control group, confirming a role for ANRIL in angiogenesis. These disease associations position ANRIL as a key target for treatment of cardiovascular disease.

\section{CHALLENGES ASSOCIATED WITH STUDYING IncRNAs}

There are many challenges associated with studying lncRNAs. The first question when studying a lncRNA is verifying whether it is truly a bona fide lncRNA. RNA-seq data is mapped to the most recent build of the human genome. These reference databases are not comprehensive with respect to lncRNA annotation, thus limiting discovery. Moreover, lncRNAs are typically rare transcripts. Many are only expressed in specific contexts (e.g., development, disease, specific environmental stimuli, etc.), which can make discovery difficult. This review does not address the emerging concepts on the role of lncRNAs as post-transcriptional modifiers of gene expression and function. We and others have recently addressed the cytoplasmic function of lncRNAs (Rashid et al., 2016; Noh et al., 2018; Aillaud and Schulte, 2020; Ho et al., 2021). We also acknowledge that a key concept, and one that warrants deeper study, is the shuttling of lncRNAs in and out of the nucleus. Moreover, the varied RNA transcripts derived from specific lncRNA genes may have distinct subcellular locations. It is paramount that the candidate lncRNA structure and diversity be assessed before proceeding with detailed mechanistic and functional studies.

The paradigm that a gene must have either protein-coding or a non-coding function, but not both, is too simplistic. Some RNAs have both coding and non-coding functions (Robb et al., 2004; Fish et al., 2007). The sONE RNA, is a lncRNA antisense to eNOS that exhibits exon/exon sense/antisense interactions. The sONE locus also has a minor mRNA variant that encodes a protein involved in the autophagy pathway. Human ECs have high levels of eNOS mRNA, but low levels of sONE RNA. When sONE RNA is overexpressed, there is decreased eNOS $\mathrm{mRNA}$ and protein expression. Adding to this, sONE RNA is upregulated by hypoxia in ECs and VSMCs. Notably, sONE is primarily localized to the nucleus in normoxia, but with hypoxia, the sONE RNA is shuttled into the cytoplasm.

LncRNAs exhibit protean intra-species allelic diversity. Furthermore, it follows and has been noted that lncRNAs have low inter-species sequence conservation, likely due to rapid evolutionary turnover (Hezroni et al., 2015; Quinn et al., 2016). For lncRNA homologs, generally the length of an alignable sequence is about 5 times shorter than that of a protein-coding gene. A normal lncRNA that is conserved between humans and mice will have about $20 \%$ interspecies homology, which decreases to about $5 \%$ in fish. As a result, lncRNAs may be absent in model organisms, making it hard for scientists to not only discover lncRNAs, but also to assess their in vivo function. There is some sequence conservation in lncRNAs, typically in short sequence islands, and perhaps this is because these are regions that are required for specific interactions with other RNAs, proteins or DNA (Kapusta and Feschotte, 2014; Quinn et al., 2016; Ulitsky, 2016). However, there are other factors to consider in the discussion of conservation besides sequence similarity alone. In fact, scientists have identified many orthologous RNAs with highly divergent sequences, that they would no longer be identifiable as orthologs by sequence similarity alone, but their function is preserved (Ponjavic et al., 2007; Ulitsky et al., 2011; Ulitsky, 2016). Another factor is positional conservation in which lncRNAs can be detected from syntenic loci even in the absence of most, if not all sequence similarity. It is clear that we need to define lncRNA conservation traits/signals. Another debated factor is structural conservation. Scientists have shown that there is limited association between secondary structure and sequence conservation (Managadze et al., 2011; Yang and Zhang, 2015). 
Moreover, there is evidence that specific lncRNAs act through specific tertiary or quaternary structural features, such as the triplex elements at the $3^{\prime}$-termini of MALAT1 or Nuclear Enriched Abundant Transcript 1 (NEAT1) (Wilusz et al., 2012). Further study on IncRNA structural conservation is evidently needed to improve our understanding on inter- and intra-species lncRNA conservation.

\section{NEW FRONTIERS: LncRNAs AS DIAGNOSTIC AND THERAPEUTIC TARGETS IN MEDICINE}

As we look toward the next decade of lncRNA research, it will be interesting to see more clinical studies evaluating whether lncRNAs have the potential to be used as biomarkers or therapeutic targets for clinical interventions to improve disease outcomes. LncRNAs are lowly expressed, so we know quantification in biological fluids will be challenging. Moreover, they are poorly conserved across species making them difficult to study using in vivo models of disease. However, lncRNAs can be highly tissue-specific, which sets up these molecules to be very specific biomarkers. To date, prostate cancer antigen 3 (PCA3) is the only lncRNA approved as a clinical diagnostic biomarker for early detection of prostate cancer (Groskopf et al., 2006).

As for targeting lncRNAs, many scientists agree that the key will be through identifying the optimal delivery system. There has been growing interest in recent years in extracellular vesicles. Though we did not discuss it in this review, many lncRNAs, especially those expressed in cancer, have also been shown to be secreted by extracellular vesicles (Wu et al., 2017; TellezGabriel and Heymann, 2019; Zhao et al., 2019; Fan et al., 2020). Extracellular vesicles are of interest because they are encapsulated by a lipid bilayer, which overcomes concerns with stability. In addition, extracellular vesicles have less immunogenicity and higher in vivo stability compared to widely used viral and non-viral vectors (Chen et al., 2021). Exosomes, a subtype of extracellular vesicles, are currently being examined. They have poor efficiency with respect to packaging large nucleic acids, but this is overcome through integration with liposomes or nanoparticles, which improves both specificity and control of delivery. Recent work has found that exosome-liposome hybrids were able to successfully deliver CRISPR-Cas9 systems in vitro and in vivo (Lin et al., 2018; Tao et al., 2018). This is particularly exciting for the future of precision medicine. Importantly, exosomal studies are not without challenge. There is a high degree of heterogeneity in vesicles, variability between

\section{REFERENCES}

Ackermann, M., Houdek, J. P., Gibney, B. C., Ysasi, A., Wagner, W., Belle, J., et al. (2014). Sprouting and intussusceptive angiogenesis in postpneumonectomy lung growth: mechanisms of alveolar neovascularization. Angiogenesis 17, 541551. doi: 10.1007/s10456-013-9399-9

Adair, T. H., and Montani, J.-P. (2010). Angiogenesis. Colloquium Ser. Integr. Syst. Physiol. Mol. Funct. 2, 1-84. doi: 10.4199/C00017ED1V01Y201009ISP 010 in vitro and in vivo findings, and difficulty in determining vesicle origin or destination. Advances in isolating and characterizing extracellular vesicle-associated lncRNAs will significantly help move the field forward and has the potential to revolutionize clinical medicine.

Notably, even once we are able to identify "druggable" lncRNAs, it is still unclear what the downstream or off-target effects would be and if they would be adverse. Until clinical trials are conducted, the safety and efficacy of lncRNAs as therapeutic targets remains unknown. Evidently, the emerging study of lncRNAs has many challenges, but recent work underscores the importance of the contribution of lncRNAs to the regulation of angiogenesis in health and disease.

\section{CONCLUSION}

Our review is an overview of angiogenic long non-coding RNAs, and their epigenetic regulation of the vascular endothelium. The functional properties of the vascular endothelium are diverse and heterogeneous between vascular beds. Our understanding of angiogenesis to date has largely focused on protein signaling, but recent work by scientists has revealed that long non-coding RNAs, which are a functionally diverse class of molecules, are involved in regulating this process. As the function of lncRNAs is often dependent on their subcellular localization, nuclear lncRNAs act as epigenetic modifiers. Scientists have begun to identify and characterize a sub-class of lncRNAs: angiogenic lncRNAs. This includes: STEEL, GATA6-AS, and MANTIS, and the disease-associated angiogenic lncRNAs: MEG3, MALAT1, or ANRIL. Taken together, these emerging concepts may provide a novel avenue for therapeutic targets or biomarkers for disease in the next decade.

\section{AUTHOR CONTRIBUTIONS}

NS, RN, and PAM drafted and edited the manuscript. All authors read and approved the manuscript.

\section{FUNDING}

NS and RN were recipients of the Queen Elizabeth II Graduate Scholarships in Science and Technology. This work was supported by a grant to PAM from the Heart and Stroke Foundation of Canada (G-19-0026562).

Adams, R. H., and Alitalo, K. (2007). Molecular regulation of angiogenesis and lymphangiogenesis. Nat. Rev. Mol. Cell Biol. 8, 464-478. doi: 10.1038/nrm2183

Aillaud, M., and Schulte, L. N. (2020). Emerging roles of long noncoding RNAs in the Cytoplasmic Milieu. ncRNA 6:44. doi: 10.3390/ncrna604 0044

Anderson, K. P., Kern, C. B., Crable, S. C., and Lingrel, J. B. (1995). Isolation of a gene encoding a functional zinc finger protein homologous to erythroid Krüppel-like factor: identification of a new multigene family. Mol. Cell. Biol. 15, 5957-5965. doi: 10.1128/MCB.15.11.5957 
Apweiler, R., Bairoch, A., Wu, C. H., Barker, W. C., Boeckmann, B., Ferro, S., et al. (2004). UniProt: the Universal Protein knowledgebase. Nucleic Acids Res. 32, D115-D119. doi: 10.1093/nar/gkh131

Atkins, G. B., Wang, Y., Mahabeleshwar, G. H., Shi, H., Gao, H., Kawanami, D., et al. (2008). Hemizygous deficiency of Krüppel-like factor 2 augments experimental atherosclerosis. Circ. Res. 103, 690-693. doi: 10.1161/CIRCRESAHA.108.184663

Autuoro, J., Pirnie, S., and Carmichael, G. (2014). Long noncoding RNAs in imprinting and X Chromosome inactivation. Biomolecules 4, 76-100. doi: 10. 3390/biom4010076

Awwad, D. A. (2019). Beyond classic editing: innovative CRISPR approaches for functional studies of long non-coding RNA. Biol. Methods Protoc. 4:bz017. doi: 10.1093/biomethods/bpz017

Bai, Y., Nie, S., Jiang, G., Zhou, Y., Zhou, M., Zhao, Y., et al. (2014). Regulation of CARD8 expression by ANRIL and Association of CARD8 single nucleotide polymorphism rs2043211 (p.C10X) With Ischemic stroke. Stroke 45, 383-388. doi: 10.1161/STROKEAHA.113.003393

Battistella, M., and Marsden, P. (2015). Advances, nuances, and potential pitfalls when exploiting the therapeutic potential of RNA interference. Clin. Pharmacol. Ther. 97, 79-87. doi: 10.1002/cpt.8

Bell, J. C., Jukam, D., Teran, N. A., Risca, V. I., Smith, O. K., Johnson, W. L., et al. (2018). Chromatin-associated RNA sequencing (ChAR-seq) maps genomewide RNA-to-DNA contacts. Elife 7:e27024. doi: 10.7554/eLife.27024

Bentley, K., Mariggi, G., Gerhardt, H., and Bates, P. A. (2009). Tipping the balance: robustness of tip cell selection, migration and fusion in angiogenesis. PLoS Comput. Biol. 5:e1000549. doi: 10.1371/journal.pcbi.1000549

Bignon, M., Pichol-Thievend, C., Hardouin, J., Malbouyres, M., Bréchot, N., Nasciutti, L., et al. (2011). Lysyl oxidase-like protein-2 regulates sprouting angiogenesis and type IV collagen assembly in the endothelial basement membrane. Blood 118, 3979-3989. doi: 10.1182/blood-2010-10-313296

Biswas, S., Feng, B., Chen, S., Liu, J., Aref-Eshghi, E., Gonder, J., et al. (2021). The long Non-Coding RNA HOTAIR is a critical epigenetic mediator of angiogenesis in diabetic retinopathy. Invest. Ophthalmol. Vis. Sci. 62:20. doi: 10.1167/iovs.62.3.20

Bonetti, A., Agostini, F., Suzuki, A. M., Hashimoto, K., Pascarella, G., Gimenez, J., et al. (2020). RADICL-seq identifies general and cell type-specific principles of genome-wide RNA-chromatin interactions. Nat. Commun. 11:1018. doi: 10. 1038/s41467-020-14337-6

Boon, R. A., Hofmann, P., Michalik, K. M., Lozano-Vidal, N., Berghäuser, D., Fischer, A., et al. (2016). Long Noncoding RNA Meg3 controls endothelial cell aging and function. J. Am. Col. Cardiol. 68, 2589-2591. doi: 10.1016/j.jacc.2016. 09.949

Broadbent, H. M., Peden, J. F., Lorkowski, S., Goel, A., Ongen, H., Green, F., et al. (2008). Susceptibility to coronary artery disease and diabetes is encoded by distinct, tightly linked SNPs in the ANRIL locus on chromosome 9p. Hum. Mol. Genet. 17, 806-814. doi: 10.1093/hmg/ddm352

Burd, C. E., Jeck, W. R., Liu, Y., Sanoff, H. K., Wang, Z., and Sharpless, N. E. (2010). Expression of linear and novel circular forms of an INK4/ARF-associated NonCoding RNA correlates with atherosclerosis risk. PLoS Genet 6:e1001233. doi: 10.1371/journal.pgen.1001233

Cabili, M. N., Dunagin, M. C., McClanahan, P. D., Biaesch, A., Padovan-Merhar, O., Regev, A., et al. (2015). Localization and abundance analysis of human lncRNAs at single-cell and single-molecule resolution. Genome Biol. 16:20. doi: 10.1186/s13059-015-0586-4

Cai, P., Otten, A. B. C., Cheng, B., Ishii, M. A., Zhang, W., Huang, B., et al. (2020). A genome-wide long noncoding RNA CRISPRi screen identifies PRANCR as a novel regulator of epidermal homeostasis. Genome Res. 30, 22-34. doi: 10.1101/ gr.251561.119

Cai, X., and Cullen, B. R. (2007). The imprinted H19 noncoding RNA is a primary microRNA precursor. RNA 13, 313-316. doi: 10.1261/rna.351707

Carmeliet, P., Ferreira, V., Breier, G., Pollefeyt, S., Kieckens, L., Gertsenstein, M., et al. (1996). Abnormal blood vessel development and lethality in embryos lacking a single VEGF allele. Nature 380, 435-439. doi: 10.1038/380435a0

Carninci, P., Kasukawa, T., Katayama, S., Gough, J., Frith, M. C., Maeda, N., et al. (2021). The transcriptional landscape of the mammalian genome. Science 309:6.

Chappell, J. C., Wiley, D. M., and Bautch, V. L. (2011). Regulation of blood vessel sprouting. Seminars Cell Dev. Biol. 22, 1005-1011. doi: 10.1016/j.semcdb.2011. 10.006
Chaudhuri, A. R., and Nussenzweig, A. (2017). The multifaceted roles of PARP1 in DNA repair and chromatin remodelling. Nat. Rev. Mol. Cell. Biol. 18, 610-621. doi: 10.1038/nrm.2017.53

Chen, L., Endler, A., and Shibasaki, F. (2009). Hypoxia and angiogenesis: regulation of hypoxia-inducible factors via novel binding factors. Exp. Mol. Med. 41:849. doi: 10.3858/emm.2009.41.12.103

Chen, Y., Li, Z., Chen, X., and Zhang, S. (2021). Long non-coding RNAs: From disease code to drug role. Acta Pharmaceutica Sinica B 11, 340-354. doi: 10. 1016/j.apsb.2020.10.001

Cheng, J., Kapranov, P., Drenkow, J., Dike, S., Brubaker, S., Patel, S., et al. (2005). Transcriptional maps of 10 human chromosomes at 5-Nucleotide resolution. Science 308, 1149-1154. doi: 10.1126/science. 1108625

Chery, J. (2016). RNA therapeutics: RNAi and antisense mechanisms and clinical applications. Postdoc. J. 4, 35-50.

Chu, C., Qu, K., Zhong, F. L., Artandi, S. E., and Chang, H. Y. (2011). Genomic maps of long Noncoding RNA occupancy reveal principles of RNA-Chromatin interactions. Mol. Cell 44, 667-678. doi: 10.1016/j.molcel.2011.08.027

Cines, D. B., Pollak, E. S., Buck, C. A., Loscalzo, J., Zimmerman, G. A., McEver, R. P., et al. (1998). Endothelial cells in physiology and in the pathophysiology of vascular disorders. Blood 91, 3527-3561.

Collins, M. L., Irvine, B., Tyner, D., Fine, E., Zayati, C., Chang, C., et al. (1997). A branched DNA signal amplification assay for quantification of nucleic acid targets below 100 molecules/ml. Nucleic Acids Res. 25, 2979-2984. doi: 10.1093/ nar/25.15.2979

Congrains, A., Kamide, K., Oguro, R., Yasuda, O., Miyata, K., Yamamoto, E., et al. (2012). Genetic variants at the 9p21 locus contribute to atherosclerosis through modulation of ANRIL and CDKN2A/B. Atherosclerosis 220, 449-455. doi: 10.1016/j.atherosclerosis.2011.11.017

Crooke, S. T. (2017). Molecular mechanisms of antisense oligonucleotides. Nucleic Acid Ther. 27, 70-77. doi: 10.1089/nat.2016.0656

Dekker, J., Rippe, K., Dekker, M., and Kleckner, N. (2002a). Capturing chromosome conformation. Science 295, 1306-1311. doi: 10.1126/science.1067799

Dekker, R. J., van Soest, S., Fontijn, R. D., Salamanca, S., de Groot, P. G., VanBavel, E., et al. (2002b). Prolonged fluid shear stress induces a distinct set of endothelial cell genes, most specifically lung Krüppel-like factor (KLF2). Blood 100, 16891698. doi: 10.1182/blood-2002-01-0046

Dekker, R. J., van Thienen, J. V., Rohlena, J., de Jager, S. C., Elderkamp, Y. W., Seppen, J., et al. (2005). Endothelial KLF2 links local arterial shear stress levels to the expression of vascular tone-regulating genes. Am. J. Pathol. 167, 609-618. doi: 10.1016/S0002-9440(10)63002-7

del Toro, R., Prahst, C., Mathivet, T., Siegfried, G., Kaminker, J. S., Larrivee, B., et al. (2010). Identification and functional analysis of endothelial tip cell-enriched genes. Blood 116, 4025-4033. doi: 10.1182/blood-2010-02-270819

Derrien, T., Johnson, R., Bussotti, G., Tanzer, A., Djebali, S., Tilgner, H., et al. (2012). The GENCODE v7 catalog of human long noncoding RNAs: Analysis of their gene structure, evolution, and expression. Genome Res. 22, 1775-1789. doi: $10.1101 /$ gr.132159.111

Djebali, S., Davis, C. A., Merkel, A., Dobin, A., Lassmann, T., Mortazavi, A., et al. (2012). Landscape of transcription in human cells. Nature 489, 101-108. doi: $10.1038 /$ nature 11233

Dorsett, Y., and Tuschl, T. (2004). siRNAs: applications in functional genomics and potential as therapeutics. Nat. Rev. Drug Discov. 3, 318-329. doi: 10.1038/ $\operatorname{nrd} 1345$

Duffy, S. J., Tran, B. T., New, G., Tudball, R. N., Esler, M. D., Harper, R. W., et al. (1998). Continuous release of vasodilator prostanoids contributes to regulation of resting forearm blood flow in humans. Am. J. Physiol. Heart Circ. Physiol. 274, H1174-H1183. doi: 10.1152/ajpheart.1998.274.4.H1174

Edgren, H., Murumagi, A., Kangaspeska, S., Nicorici, D., Hongisto, V., Kleivi, K., et al. (2011). Identification of fusion genes in breast cancer by paired-end RNA-sequencing. Genome Biol. 12:R6. doi: 10.1186/gb-2011-12$1-r 6$

Eilken, H. M., and Adams, R. H. (2010). Dynamics of endothelial cell behavior in sprouting angiogenesis. Curr. Opin. Cell Biol. 22, 617-625. doi: 10.1016/j.ceb. 2010.08.010

Eißmann, M., Gutschner, T., Hämmerle, M., Günther, S., Caudron-Herger, M., Groß, M., et al. (2012). Loss of the abundant nuclear non-coding RNA MALAT1 is compatible with life and development. RNA Biol. 9, 1076-1087. doi: 10.4161/ rna.21089 
Engreitz, J. M., Pandya-Jones, A., McDonel, P., Shishkin, A., Sirokman, K., Surka, C., et al. (2013). The Xist lncRNA exploits three-dimensional genome architecture to spread across the X Chromosome. Science 341:1237973. doi: 10.1126/science. 1237973

Engreitz, J. M., Sirokman, K., McDonel, P., Shishkin, A. A., Surka, C., Russell, P., et al. (2014). RNA-RNA interactions enable specific targeting of Noncoding RNAs to Nascent Pre-mRNAs and chromatin sites. Cell 159, 188-199. doi: 10.1016/j.cell.2014.08.018

Fan, T., Sun, N., and He, J. (2020). Exosome-derived LncRNAs in lung cancer. Front. Oncol. 10:1728. doi: 10.3389/fonc.2020.01728

Fang, S., Zhang, L., Guo, J., Niu, Y., Wu, Y., Li, H., et al. (2018). NONCODEV5: a comprehensive annotation database for long non-coding RNAs. Nucleic Acids Res. 46, D308-D314. doi: 10.1093/nar/gkx1107

Fang, Y., Xu, Y., Wang, R., Hu, L., Guo, D., Xue, F., et al. (2020). Recent advances on the roles of LncRNAs in cardiovascular disease. J. Cell. Mol. Med. 24, 12246-12257. doi: $10.1111 / \mathrm{jcmm} .15880$

Fazal, F. M., Han, S., Parker, K. R., Kaewsapsak, P., Xu, J., Boettiger, A. N., et al. (2019). Atlas of subcellular RNA localization revealed by APEX-Seq. Cell 178, 473-490. doi: 10.1016/j.cell.2019.05.027

Ferrara, N., Carver-Moore, K., Chen, H., Dowd, M., Lu, L., O’Shea, K. S. et al. (1996). Heterozygous embryonic lethality induced by targeted inactivation of the VEGF gene. Nature 380, 439-442. doi: 10.1038/380 $439 \mathrm{a} 0$

Fish, J. E., Matouk, C. C., Yeboah, E., Bevan, S. C., Khan, M., Patil, K., et al. (2007). Hypoxia-inducible expression of a natural cis-antisense transcript inhibits endothelial Nitric-oxide Synthase. J. Biol. Chem. 282, 15652-15666. doi: 10. 1074/jbc.M608318200

Foroud, T., Koller, D. L., Lai, D., Sauerbeck, L., Anderson, C., Ko, N., et al. (2012). Genome-wide association study of intracranial aneurysms confirms role of Anril and SOX17 in Disease Risk. Stroke 43, 2846-2852. doi: 10.1161/ STROKEAHA.112.656397

Fu, G. K., Xu, W., Wilhelmy, J., Mindrinos, M. N., Davis, R. W., Xiao, W., et al. (2014). Molecular indexing enables quantitative targeted RNA sequencing and reveals poor efficiencies in standard library preparations. Proc. Natl. Acad. Sci. U S A 111, 1891-1896. doi: 10.1073/pnas.1323732111

Gall, J. G., and Pardue, M. L. (1969). Formation and detection of RNA-DNA hybrid molecules in cytological preparatiONS. PNAS 63, 378-383. doi: 10.1073/pnas. 63.2.378

Gan, L., Liao, S., Xing, Y., and Deng, S. (2021). The regulatory functions of lncRNAs on Angiogenesis following ischemic stroke. Front. Mol. Neurosci. 13:613976. doi: $10.3389 /$ fnmol.2020.613976

Gavard, J., and Gutkind, J. S. (2008). VE-cadherin and claudin-5: it takes two to tango. Nat. Cell Biol. 10, 883-885. doi: 10.1038/ncb0808-883

Gong, N., Teng, X., Li, J., and Liang, X.-J. (2019). Antisense oligonucleotideconjugated nanostructure-targeting lncRNA MALAT1 inhibits cancer metastasis. ACS Appl. Mater. Interfaces 11, 37-42. doi: 10.1021/acsami.8b18288

Gordon, F. E., Nutt, C. L., Cheunsuchon, P., Nakayama, Y., Provencher, K. A., Rice, K. A., et al. (2010). Increased expression of angiogenic genes in the brains of mouse Meg3-Null Embryos. Endocrinology 151, 2443-2452. doi: 10.1210/en. 2009-1151

Goyal, A., Myacheva, K., Groß, M., Klingenberg, M., Duran Arqué, B., and Diederichs, S. (2017). Challenges of CRISPR/Cas9 applications for long non-coding RNA genes. Nucleic Acids Res. 45:e12. doi: 10.1093/nar/gk w883

Groskopf, J., Aubin, S. M. J., Deras, I. L., Blase, A., Bodrug, S., Clark, C., et al. (2006). APTIMA PCA3 molecular urine test: development of a method to aid in the diagnosis of prostate cancer. Clin. Chem. 52, 1089-1095. doi: 10.1373/clinchem. 2005.063289

Gutschner, T., Hämmerle, M., and Diederichs, S. (2013). MALAT1 - a paradigm for long noncoding RNA function in cancer. J. Mol. Med. 91, 791-801. doi: 10.1007/s00109-013-1028-y

Guttman, M., Amit, I., Garber, M., French, C., Lin, M. F., Feldser, D., et al. (2009). Chromatin signature reveals over a thousand highly conserved large non-coding RNAs in mammals. Nature 458, 223-227. doi: 10.1038/nature0 7672

Hacisuleyman, E., Goff, L. A., Trapnell, C., Williams, A., Henao-Mejia, J., Sun, L., et al. (2014). Topological organization of Multi-chromosomal regions by firre. Nat. Struct. Mol. Biol. 21, 198-206. doi: 10.1038/nsmb.2764
Hadfield, J., and Retief, J. (2018). A profusion of confusion in NGS methods naming. Nat. Methods 15, 7-8. doi: 10.1038/nmeth.4558

Han, J., Zhang, Z., and Wang, K. (2018). 3C and 3C-based techniques: the powerful tools for spatial genome organization deciphering. Mol. Cytogenet. 11:21. doi: 10.1186/s13039-018-0368-2

Harrow, J., Frankish, A., Gonzalez, J. M., Tapanari, E., Diekhans, M., Kokocinski, F., et al. (2012). GENCODE: the reference human genome annotation for The ENCODE Project. Genome Res. 22, 1760-1774. doi: 10.1101/gr.135350.111

He, C., Yang, W., Yang, J., Ding, J., Li, S., Wu, H., et al. (2017). Long Noncoding RNA MEG3 negatively regulates proliferation and angiogenesis in vascular endothelial cells. DNA Cell Biol. 36, 475-481. doi: 10.1089/dna.2017.3682

Hezroni, H., Koppstein, D., Schwartz, M. G., Avrutin, A., Bartel, D. P., and Ulitsky, I. (2015). Principles of long Noncoding RNA evolution derived from direct comparison of transcriptomes in 17 species. Cell Rep. 11, 1110-1122. doi: 10. 1016/j.celrep.2015.04.023

Ho, J. J. D., Man, J. H. S., Schatz, J. H., and Marsden, P. A. (2021). Translational remodeling by RNA -binding proteins and noncoding RNAs. Wiley interdiscip. Rev. RNA 2021:e1647. doi: 10.1002/wrna.1647

Holdt, 1. M., beutner, f., scholz, m., gielen, s., gäbel, g., bergert, h., et al. (2010). ANRIL expression is associated with atherosclerosis risk at chromosome 9p21. Arterioscler. Thromb. Vasc. Bio. 30, 620-627. doi: 10.1161/ATVBAHA.109. 196832

Holdt, L. M., and Teupser, D. (2018). Long Noncoding RNA ANRIL: Lnc-ing genetic variation at the chromosome 9p21 locus to molecular mechanisms of atherosclerosis. Front. Cardiovasc. Med. 5:145. doi: 10.3389/fcvm.2018.00145

Hou, Y., Zhang, R., and Sun, X. (2019). Enhancer LncRNAs influence chromatin interactions in different ways. Front Genet. 10:936. doi: 10.3389/fgene.2019. 00936

Hu, X., Tang, J., Hu, X., Bao, P., Deng, W., Wu, J., et al. (2019). Silencing of long Non-coding RNA HOTTIP reduces inflammation in rheumatoid arthritis by demethylation of SFRP1. Mol. Ther. Nucleic Acids 19, 468-481. doi: 10.1016/j. omtn.2019.11.015

Huang, J., Ma, L., Song, W., Lu, B., Huang, Y., Dong, H., et al. (2017). LncRNAMALAT1 promotes angiogenesis of thyroid cancer by modulating tumorassociated macrophage FGF2 protein secretion: the mechanisms of malat1 in TAMs. J. Cell. Biochem. 118, 4821-4830. doi: 10.1002/jcb.26153

Huang, Q., Pan, M., Zhou, J., and Yin, F. (2020). Overexpression of long noncoding RNA ANRIL promotes post-ischaemic angiogenesis and improves cardiac functions by targeting Akt. J. Cell. Mol. Med. 24, 6860-6868. doi: 10. $1111 / \mathrm{jcmm} .15343$

Hubberten, M., Bochenek, G., Chen, H., Häsler, R., Wiehe, R., Rosenstiel, P., et al. (2019). Linear isoforms of the long noncoding RNA CDKN2B-AS1 regulate the c-myc-enhancer binding factor RBMS1. Eur. J. Hum. Genet. 27, 80-89. doi: 10.1038/s41431-018-0210-7

Iaconetti, C., Gareri, C., Polimeni, A., and Indolfi, C. (2013). Non-coding RNAs: The "dark Matter" of cardiovascular pathophysiology. Int. J. Mol. Sci. 14, 19987-20018. doi: 10.3390/ijms141019987

Ismail, N., Abdullah, N., Abdul Murad, N. A., Jamal, R., and Sulaiman, S. A. (2021). Long Non-coding RNAs (lncRNAs) in cardiovascular disease complication of Type 2 diabetes. Diagnostics 11:145. doi: 10.3390/diagnostics11010145

Iyer, S., Modali, S. D., and Agarwal, S. K. (2017). Long Noncoding RNA MEG3 Is an epigenetic determinant of oncogenic signaling in functional pancreatic neuroendocrine tumor cells. Mol. Cell. Biol. 37:e00278-17. doi: 10.1128/MCB. 00278-17

Jain, R. K. (2005). Normalization of tumor vasculature: an emerging concept in antiangiogenic therapy. Science 307, 58-62.

Jin, K.-T., Yao, J.-Y., Fang, X.-L., Di, H., and Ma, Y.-Y. (2020). Roles of lncRNAs in cancer: focusing on angiogenesis. Life Sci. 252:117647. doi: 10.1016/j.lfs.2020. 117647

Jinek, M., Chylinski, K., Fonfara, I., Hauer, M., Doudna, J. A., and Charpentier, E. (2012). A programmable dual RNA-guided DNA endonuclease in adaptive bacterial immunity. Science 337, 816-821. doi: 10.1126/science.1225829

Kaewsapsak, P., Shechner, D. M., Mallard, W., Rinn, J. L., and Ting, A. Y. (2017). Live-cell mapping of organelle-associated RNAs via proximity biotinylation combined with protein-RNA crosslinking. Elife 6:e29224. doi: 10.7554/eLife. 29224

Kaneko, S., Bonasio, R., Saldaña-Meyer, R., Yoshida, T., Son, J., Nishino, K., et al. (2014). Interactions between JARID2 and Noncoding RNAs Regulate PRC2 
recruitment to chromatin. Mol. Cell 53, 290-300. doi: 10.1016/j.molcel.2013. 11.012

Kapusta, A., and Feschotte, C. (2014). Volatile evolution of long noncoding RNA repertoires: mechanisms and biological implications. Trends Genet. 30, 439-452. doi: 10.1016/j.tig.2014.08.004

Kato, Y., Kravchenko, V. V., Tapping, R. I., Han, J., Ulevitch, R. J., and Lee, J.-D. (1997). BMK1/ERK5 regulates serum-induced early gene expression through transcription factor MEF2C. EMBO J. 16, 7054-7066. doi: 10.1093/emboj/16. 23.7054

Katsushima, K., Jallo, G., Eberhart, C. G., and Perera, R. J. (2021). Long non-coding RNAs in brain tumors. NAR Cancer 3:41. doi: 10.1093/narcan/zcaa041

Kaunas, R., Kang, H., and Bayless, K. J. (2011). Synergistic regulation of angiogenic sprouting by biochemical factors and wall shear stress. Cell. Mol. Bioeng. 4, 547-559. doi: 10.1007/s12195-011-0208-5

Kino, T., Hurt, D., Ichijo, T., Nader, N., and Chrousos, G. (2010). Noncoding RNA Gas5 Is a growth arrest- and starvation-associated repressor of the glucocorticoid receptor. Sci. Signal. 3:ra8. doi: 10.1126/scisignal.2000568

Koch, L. (2017). Screening for lncRNA function. Nat. Rev. Genet. 18:70. doi: 10. 1038/nrg.2016.168

Koller, A., Sun, D., and Kaley, G. (1993). Role of shear stress and endothelial prostaglandins in flow- and viscosity-induced dilation of arterioles in vitro. Circ. Res. 72, 1276-1284. doi: 10.1161/01.RES.72.6.1276

Konerding, M. A., Gibney, B. C., Houdek, J. P., Chamoto, K., Ackermann, M., Lee, G. S., et al. (2012). Spatial dependence of alveolar angiogenesis in postpneumonectomy lung growth. Angiogenesis 15, 23-32. doi: 10.1007/s10456011-9236-y

Kong, Y., Sharma, R. B., Nwosu, B. U., and Alonso, L. C. (2016). Islet biology, the CDKN2A/B locus and type 2 diabetes risk. Diabetologia 59, 1579-1593. doi: 10.1007/s00125-016-3967-7

Kremer, P. H. C., Koeleman, B. P. C., Pawlikowska, L., Weinsheimer, S., Bendjilali, N., Sidney, S., et al. (2015). Evaluation of genetic risk loci for intracranial aneurysms in sporadic arteriovenous malformations of the brain. J. Neurol. Neurosurg. Psychiatry 86, 524-529. doi: 10.1136/jnnp-2013-307276

Ku, K. H., Dubinsky Michelle, K., Sukumar Aravin, N., Subramaniam, N., Feasson, M. Y. M., Nair, R., et al. (2021). In vivo function of flow-responsive Cis-DNA elements of the endothelial nitric oxide synthase gene: A role for chromatinbased mechanisms. Circulation 2021:1078. doi: 10.1161/CIRCULATIONAHA. 120.051078

Ku, K. H., Subramaniam, N., and Marsden, P. A. (2019). Epigenetic determinants of flow-mediated vascular endothelial gene expression. Hypertension 74, 467-476. doi: 10.1161/HYPERTENSIONAHA.119.13342

Le, N.-T., Heo, K.-S., Takei, Y., Lee, H., Woo, C.-H., Chang, E., et al. (2013). A crucial role for p90RSK-mediated reduction of ERK5 transcriptional activity in endothelial dysfunction and atherosclerosis. Circulation 127, 486-499. doi: 10.1161/CIRCULATIONAHA.112.116988

Lee, J. H., Daugharthy, E. R., Scheiman, J., Kalhor, R., Ferrante, T. C., Terry, R., et al. (2015). Fluorescent in situ sequencing (FISSEQ) of RNA for gene expression profiling in intact cells and tissues. Nat. Protoc. 10, 442-458. doi: $10.1038 /$ nprot.2014.191

Leisegang, M. S., Bibli, S.-I., Günther, S., Pflüger-Müller, B., Oo, J. A., Höper, C., et al. (2019). Pleiotropic effects of laminar flow and statins depend on the Krüppel-like factor-induced lncRNA MANTIS. Eur. Heart J. 40, 2523-2533. doi: 10.1093/eurheartj/ehz393

Leisegang, M. S., Fork, C., Josipovic, I., Richter, F. M., Preussner, J., Hu, J., et al. (2017). Long Noncoding RNA MANTIS facilitates endothelial angiogenic function. Circulation 136, 65-79. doi: 10.1161/CIRCULATIONAHA.116. 026991

Lerner, M. R., and Steitz, J. A. (1979). Antibodies to small nuclear RNAs complexed with proteins are produced by patients with systemic lupus erythematosus. PNAS 76, 5495-5499. doi: 10.1073/pnas.76.11.5495

Li, J., Hou, R., Niu, X., Liu, R., Wang, Q., Wang, C., et al. (2016). Comparison of microarray and RNA-Seq analysis of mRNA expression in dermal mesenchymal stem cells. Biotechnol. Lett. 38, 33-41. doi: 10.1007/s10529-0151963-5

Li, K., Blum, Y., Verma, A., Liu, Z., Pramanik, K., Leigh, N. R., et al. (2010). A noncoding antisense RNA in tie-1 locus regulates tie-1 function in vivo. Blood 115, 133-139. doi: 10.1182/blood-2009-09-242180
Li, X., and Fu, X.-D. (2019). Chromatin-associated RNAs as facilitators of functional genomic interactions. Nat. Rev. Genet. 20, 503-519. doi: 10.1038/ s41576-019-0135-1

Li, X., Zhou, B., Chen, L., Gou, L.-T., Li, H., and Fu, X.-D. (2017). GRID-seq reveals the global RNA-chromatin interactome. Nat. Biotechnol. 35, 940-950. doi: $10.1038 /$ nbt. 3968

Li, X.-L., Zhou, J., Chen, Z.-R., and Chng, W.-J. (2015). p53 mutations in colorectal cancer- molecular pathogenesis and pharmacological reactivation. World J. Gastroenterol. 21, 84-93. doi: 10.3748/wjg.v21.i1.84

Li, Y., Wu, Z., Yuan, J., Sun, L., Lin, L., Huang, N., et al. (2017). Long noncoding RNA MALAT1 promotes gastric cancer tumorigenicity and metastasis by regulating vasculogenic mimicry and angiogenesis. Cancer Lett. 395, 31-44. doi: 10.1016/j.canlet.2017.02.035

Lieberman-Aiden, E., van Berkum, N. L., Williams, L., Imakaev, M., Ragoczy, T., Telling, A., et al. (2009). Comprehensive mapping of long range interactions reveals folding principles of the human genome. Science 326, 289-293. doi: $10.1126 /$ science. 1181369

Lin, M. F., Jungreis, I., and Kellis, M. (2011). PhyloCSF: a comparative genomics method to distinguish protein coding and non-coding regions. Bioinformatics 27, i275-i282. doi: 10.1093/bioinformatics/btr209

Lin, Y., Wu, J., Gu, W., Huang, Y., Tong, Z., Huang, L., et al. (2018). Exosomeliposome hybrid nanoparticles deliver CRISPR/Cas9 system in MSCs. Adv. Sci. 5:1700611. doi: 10.1002/advs.201700611

Lipowsky, H. H. (1995). "Shear Stress in the Circulation," in Flow-Dependent Regulation of Vascular Function, eds J. A. Bevan, G. Kaley, and G. M. Rubanyi (New York: Springer), 28-45.

Liu, S. J., Horlbeck, M. A., Cho, S. W., Birk, H. S., Malatesta, M., He, D., et al. (2017). CRISPRi-based genome-scale identification of functional long noncoding RNA loci in human cells. Science 355:7111. doi: 10.1126/science.aah7111

Liu, S. J., Malatesta, M., Lien, B. V., Saha, P., Thombare, S. S., Hong, S. J., et al. (2020). CRISPRi-based radiation modifier screen identifies long non-coding RNA therapeutic targets in glioma. Genome Biol. 21:83. doi: 10.1186/s13059020-01995-4

Liu, Y., Morley, M., Brandimarto, J., Hannenhalli, S., Hu, Y., Ashley, E. A., et al. (2015). RNA-Seq identifies novel myocardial gene expression signatures of heart failure. Genomics 105, 83-89. doi: 10.1016/j.ygeno.2014.12.002

Lu, Y. W., Martino, N., Gerlach, B. D., Lamar, J. M., Vincent, P. A., Adam, A. P., et al. (2021). MEF2 (myocyte enhancer factor 2) is essential for endothelial homeostasis and the atheroprotective gene expression program. Arterioscler. Thromb. Vasc. Biol. 41, 1105-1123. doi: 10.1161/ATVBAHA.120.314978

Ma, L., Cao, J., Liu, L., Du, Q., Li, Z., Zou, D., et al. (2019). LncBook: a curated knowledgebase of human long non-coding RNAs. Nucleic Acids Res. 47, D128D134. doi: 10.1093/nar/gky960

Malek, A. M. (1999). Hemodynamic shear stress and its role in atherosclerosis. JAMA 282:2035. doi: 10.1001/jama.282.21.2035

Man, H. S. J., Sukumar, A. N., Lam, G. C., Turgeon, P. J., Yan, M. S., Ku, K. H., et al. (2018). Angiogenic patterning by STEEL, an endothelial-enriched long noncoding RNA. Proc. Natl. Acad. Sci. USA 115, 2401-2406. doi: 10.1073/pnas. 1715182115

Man, H.-S. J., and Marsden, P. A. (2019). LncRNAs and epigenetic regulation of vascular endothelium: genome positioning system and regulators of chromatin modifiers. Curr. Opin. Pharmacol. 45, 72-80. doi: 10.1016/j.coph.2019.04.012

Managadze, D., Rogozin, I. B., Chernikova, D., Shabalina, S. A., and Koonin, E. V. (2011). Negative correlation between expression level and evolutionary rate of long intergenic noncoding RNAs. Genome Biol. Evol. 3, 1390-1404. doi: $10.1093 /$ gbe/evr116

Marín-Béjar, O., and Huarte, M. (2015). RNA pulldown protocol for in vitro detection and identification of RNA-associated proteins. Methods Mol. Biol. 1206, 87-95. doi: 10.1007/978-1-4939-1369-5_8

Massie, C. E., and Mills, I. G. (2012). Mapping protein-DNA interactions using ChIP-sequencing. Methods Mol. Biol. 809, 157-173. doi: 10.1007/978-1-61779376-9_11

Matouk, C. C., and Marsden, P. A. (2008). Epigenetic regulation of vascular endothelial gene expression. Circ. Res. 102, 873-887. doi: 10.1161/CIRCRESAHA.107.171025

Mattick, J. S., and Rinn, J. L. (2015). Discovery and annotation of long noncoding RNAs. Nat. Struct. Mol. Biol. 22, 5-7. doi: 10.1038/nsmb.2942 
McPherson, R., Pertsemlidis, A., Kavaslar, N., Stewart, A., Roberts, R., Cox, D. R., et al. (2007). A common allele on chromosome 9 associated with coronary heart disease. Science 316, 1488-1491. doi: 10.1126/science.114 2447

Meng, Q., Pu, L., Luo, X., Wang, B., Li, F., and Liu, B. (2020). Regulatory roles of related long Non-coding RNAs in the process of atherosclerosis. Front. Physiol. 11:564604. doi: 10.3389/fphys.2020.564604

Mercer, T. R., Dinger, M. E., and Mattick, J. S. (2009). Long non-coding RNAs: insights into functions. Nat. Rev. Genet. 10, 155-159. doi: 10.1038/nrg2 521

Miao, Y., Ajami, N. E., Huang, T.-S., Lin, F.-M., Lou, C.-H., Wang, Y.-T., et al. (2018). Enhancer-associated long non-coding RNA LEENE regulates endothelial nitric oxide synthase and endothelial function. Nat. Commun. 9:292. doi: 10.1038/s41467-017-02113-y

Michalik, K. M., You, X., Manavski, Y., Doddaballapur, A., Zörnig, M., Braun, T., et al. (2014). Long noncoding RNA MALAT1 regulates endothelial cell function and vessel growth. Circ. Res. 114, 1389-1397. doi: 10.1161/CIRCRESAHA.114. 303265

Mishra, K., and Kanduri, C. (2019). Understanding long noncoding RNA and chromatin interactions: what we know so far. Noncoding RNA 5:54. doi: 10 . 3390/ncrna5040054

Mockler, T. C., Chan, S., Sundaresan, A., Chen, H., Jacobsen, S. E., and Ecker, J. R. (2005). Applications of DNA tiling arrays for whole-genome analysis. Genomics 85, 1-15. doi: 10.1016/j.ygeno.2004.10.005

Mondal, T., Subhash, S., Vaid, R., Enroth, S., Uday, S., Reinius, B., et al. (2015). MEG3 long noncoding RNA regulates the TGF- $\beta$ pathway genes through formation of RNA-DNA triplex structures. Nat. Commun. 6:7743. doi: 10.1038/ ncomms 8743

Nakagawa, S., Ip, J. Y., Shioi, G., Tripathi, V., Zong, X., Hirose, T., et al. (2012). Malat1 is not an essential component of nuclear speckles in mice. RNA 18, 1487-1499. doi: 10.1261/rna.033217.112

Nakaoka, H., Gurumurthy, A., Hayano, T., Ahmadloo, S., Omer, W. H., Yoshihara, K., et al. (2016). Allelic imbalance in regulation of ANRIL through chromatin interaction at 9p21 endometriosis risk locus. PLoS Genet. 12:e1005893. doi: 10.1371/journal.pgen.1005893

Nanda, V., Downing, K. P., Ye, J., Xiao, S., Kojima, Y., Spin, J. M., et al. (2016). CDKN2B regulates TGF $\beta$ signaling and smooth muscle cell investment of hypoxic neovessels. Circ. Res. 118, 230-240. doi: 10.1161/CIRCRESAHA.115. 307906

Neumann, P., Jaé, N., Knau, A., Glaser, S. F., Fouani, Y., Rossbach, O., et al. (2018). The lncRNA GATA6-AS epigenetically regulates endothelial gene expression via interaction with LOXL2. Nat. Commun. 9:237. doi: 10.1038/s41467-01702431- 1

Niu, Y., Bao, L., Chen, Y., Wang, C., Luo, M., Zhang, B., et al. (2020). HIF2-induced long noncoding RNA RAB11B-AS1 promotes hypoxia-mediated angiogenesis and breast cancer metastasis. Cancer Res. 80, 964-975. doi: 10.1158/0008-5472. CAN-19-1532

Noh, J. H., Kim, K. M., McClusky, W. G., Abdelmohsen, K., and Gorospe, M. (2018). Cytoplasmic functions of long noncoding RNAs. WIREs RNA 9:e1471. doi: $10.1002 /$ wrna.1471

Novikova, I. V., Hennelly, S. P., Tung, C.-S., and Sanbonmatsu, K. Y. (2013). Rise of the RNA machines: exploring the structure of long Non-coding RNAs. J. Mol. Biol. 425, 3731-3746. doi: 10.1016/j.jmb.2013.02.030

Ohnesorge, N., Viemann, D., Schmidt, N., Czymai, T., Spiering, D., Schmolke, M., et al. (2010). Erk5 activation elicits a vasoprotective endothelial phenotype via induction of Krüppel-like factor 4 (KLF4)*. J. Biol. Chem. 285, 26199-26210. doi: 10.1074/jbc.M110.103127

Pal, S., Datta, K., and Mukhopadhyay, D. (2001). Central role of p53 on regulation of vascular permeability factor/ vascular endothelial growth factor (VPF/VEGF) expression in mammary carcinoma. Cancer Res. 61, 6952-6957.

Parmar, K. M., Larman, B., Dai, G., Zhang, Y., Wang, E. T., Moorthy, S. N., et al. (2005). Integration of flow-dependent endothelial phenotypes by Kruppel-like factor 2. J. Clin. Invest. 116, 49-58. doi: 10.1172/JCI24 787

Peng, L., Liu, F., Yang, J., Liu, X., Meng, Y., Deng, X., et al. (2020). Probing lncRNAprotein interactions: data repositories, models, and algorithms. Front. Genet. 10:1346. doi: 10.3389/fgene.2019.01346
Pinkney, H. R., Wright, B. M., and Diermeier, S. D. (2020). The lncRNA toolkit: databases and in silico tools for lncRNA analysis. ncRNA 6:49. doi: 10.3390/ ncrna6040049

Ponjavic, J., Ponting, C. P., and Lunter, G. (2007). Functionality or transcriptional noise? Evidence for selection within long noncoding RNAs. Genome Res. 17, 556-565. doi: 10.1101/gr.6036807

Potente, M., Gerhardt, H., and Carmeliet, P. (2011). Basic and therapeutic aspects of angiogenesis. Cell 146, 873-887. doi: 10.1016/j.cell.2011.08.039

Pruitt, K. D., Brown, G. R., Hiatt, S. M., Thibaud-Nissen, F., Astashyn, A., Ermolaeva, O., et al. (2014). RefSeq: an update on mammalian reference sequences. Nucleic Acids Res. 42, D756-D763. doi: 10.1093/nar/gkt1114

Quek, X. C., Thomson, D. W., Maag, J. L. V., Bartonicek, N., Signal, B., Clark, M. B., et al. (2015). lncRNAdb v2.0: expanding the reference database for functional long noncoding RNAs. Nucleic Acids Res. 43, D168-D173. doi: 10.1093/nar/ gku988

Quinn, E. M., Cormican, P., Kenny, E. M., Hill, M., Anney, R., Gill, M., et al. (2013). Development of strategies for SNP detection in RNA-Seq Data: Application to lymphoblastoid cell lines and evaluation using 1000 genomes data. PLoS One 8:e58815. doi: 10.1371/journal.pone.0058815

Quinn, J. J., Ilik, I. A., Qu, K., Georgiev, P., Chu, C., Akhtar, A., et al. (2014). Domain ChIRP reveals the modularity of long noncoding RNA architecture, chromatin interactions, and function. Nat. Biotechnol. 32, 933-940. doi: 10. $1038 /$ nbt. 2943

Quinn, J. J., Zhang, Q. C., Georgiev, P., Ilik, I. A., Akhtar, A., and Chang, H. Y. (2016). Rapid evolutionary turnover underlies conserved lncRNA-genome interactions. Genes Dev. 30, 191-207. doi: 10.1101/gad.272187.115

Quinodoz, S., and Guttman, M. (2014). Long non-coding RNAs: An emerging link between gene regulation and nuclear organization. Trends Cell Biol. 24, 651-663. doi: 10.1016/j.tcb.2014.08.009

Rackham, O., Shearwood, A.-M. J., Mercer, T. R., Davies, S. M. K., Mattick, J. S., and Filipovska, A. (2011). Long noncoding RNAs are generated from the mitochondrial genome and regulated by nuclear-encoded proteins. RNA 17, 2085-2093. doi: 10.1261/rna.029405.111

Rashid, F., Shah, A., and Shan, G. (2016). Long Non-coding RNAs in the cytoplasm. Genom. Proteom. Bioinform. 14, 73-80. doi: 10.1016/j.gpb.2016.03.005

Reis, M., Czupalla, C. J., Ziegler, N., Devraj, K., Zinke, J., Seidel, S., et al. (2012). Endothelial Wnt/ $\beta$-catenin signaling inhibits glioma angiogenesis and normalizes tumor blood vessels by inducing PDGF-B expression. J. Exper. Med. 209, 1611-1627. doi: 10.1084/jem.20111580

Resnick, N., Collins, T., Atkinson, W., Bonthront, D. T., Dewey, C. F., and Gimbrone, M. A. (1993). Platelet-derived growth factor B chain promoter contains a cis-acting fluid shear-stress-responsive element. Med. Sci. 90, 45914595 .

Rinn, J. L., Kertesz, M., Wang, J. K., Squazzo, S. L., Xu, X., Brugmann, S. A., et al. (2007). Functional demarcation of active and silent chromatin domains in human HOX Loci by Non-coding RNAs. Cell 129, 1311-1323. doi: 10.1016/ j.cell.2007.05.022

Robb, G. B., Carson, A. R., Tai, S. C., Fish, J. E., Singh, S., Yamada, T., et al. (2004). Post-transcriptional regulation of endothelial nitric-oxide synthase by an overlapping antisense mRNA Transcript. J. Biol. Chem. 279, 37982-37996. doi: 10.1074/jbc.M400271200

Rom, A., Melamed, L., Gil, N., Goldrich, M. J., Kadir, R., Golan, M., et al. (2019). Regulation of CHD2 expression by the Chaserr long noncoding RNA gene is essential for viability. Nat. Commun. 10:5092. doi: 10.1038/s41467-019-1 3075-8

Romero-Barrios, N., Legascue, M. F., Benhamed, M., Ariel, F., and Crespi, M. (2018). Splicing regulation by long noncoding RNAs. Nucleic Acids Res. 46, 2169-2184. doi: 10.1093/nar/gky095

Ruan, W., Zhao, F., Zhao, S., Zhang, L., Shi, L., and Pang, T. (2018). Knockdown of long noncoding RNA MEG3 impairs VEGF-stimulated endothelial sprouting angiogenesis via modulating VEGFR2 expression in human umbilical vein endothelial cells. Gene 649, 32-39. doi: 10.1016/j.gene.2018. 01.072

Sangwung, P., Zhou, G., Nayak, L., Chan, E. R., Kumar, S., Kang, D.-W., et al. (2017). KLF2 and KLF4 control endothelial identity and vascular integrity. JCI Insight 2:91700. doi: 10.1172/jci.insight.91700

Schmidt, T., and Carmeliet, P. (2010). Bridges that guide and unite. Nature 465, 697-699. doi: 10.1038/465697a 
Sender, R., and Milo, R. (2021). The distribution of cellular turnover in the human body. Nat. Med. 27, 45-48. doi: 10.1038/s41591-020-01182-9

Shweiki, D., Itin, A., Soffer, D., and Keshet, E. (1992). Vascular endothelial growth factor induced by hypoxia may mediate hypoxia-initiated angiogenesis. Nature 359, 843-845. doi: 10.1038/359843a0

Simon, M. D., Wang, C. I., Kharchenko, P. V., West, J. A., Chapman, B. A., Alekseyenko, A. A., et al. (2011). The genomic binding sites of a noncoding RNA. PNAS 108, 20497-20502. doi: 10.1073/pnas.1113536108

Sonnhammer, E. L., Eddy, S. R., Birney, E., Bateman, A., and Durbin, R. (1998). Pfam: multiple sequence alignments and HMM-profiles of protein domains. Nucleic Acids Res. 26, 320-322. doi: 10.1093/nar/26.1.320

Sridhar, B., Rivas-Astroza, M., Nguyen, T. C., Chen, W., Yan, Z., Cao, X., et al. (2017). Systematic mapping of RNA-chromatin interactions in vivo. Curr. Biol. 27, 602-609. doi: 10.1016/j.cub.2017.01.011

Sultan, M., Schulz, M. H., Richard, H., Magen, A., Klingenhoff, A., Scherf, M., et al. (2008). A global view of gene activity and alternative splicing by deep sequencing of the human transcriptome. Science 321, 956-960. doi: 10.1126/ science. 1160342

Taheri, M., Eghtedarian, R., Dinger, M. E., and Ghafouri-Fard, S. (2020). Emerging roles of non-coding RNAs in the pathogenesis of type 1 diabetes mellitus. Biomed. Pharmacother. 129:110509. doi: 10.1016/j.biopha.2020.110509

Tan, C., Liu, J., Wei, J., and Yang, S. (2019). Effects of ANRIL variants on the risk of ischemic stroke: a meta-analysis. Biosci. Rep. 39:BSR20182127. doi: 10.1042/ BSR20182127

Tao, S.-C., Guo, S.-C., and Zhang, C.-Q. (2018). Modularized extracellular vesicles: the dawn of prospective personalized and precision medicine. Adv. Sci. 5:1700449. doi: 10.1002/advs.201700449

Taxman, D. J., Livingstone, L. R., Zhang, J., Conti, B. J., Iocca, H. A., Williams, K. L., et al. (2006). Criteria for effective design, construction, and gene knockdown by shRNA vectors. BMC Biotechnol. 6:7. doi: 10.1186/1472-6750-6-7

Tellez-Gabriel, M., and Heymann, D. (2019). Exosomal IncRNAs: the newest promising liquid biopsy. Cancer Drug Resist. 2, 1002-1017. doi: 10.20517/cdr. 2019.69

Teppan, J., Barth, D. A., Prinz, F., Jonas, K., Pichler, M., and Klec, C. (2020). Involvement of long Non-coding RNAs (lncRNAs) in tumor angiogenesis. Noncoding RNA 6:42. doi: 10.3390/ncrna6040042

Encode Project Consortium. (2012). An integrated encyclopedia of DNA elements in the human genome. Nature 489, 57-74. doi: 10.1038/nature11247

Thomas, A. A., Feng, B., and Chakrabarti, S. (2017). ANRIL: A Regulator of VEGF in Diabetic Retinopathy. Invest. Ophthalmol. Vis. Sci. 58:470. doi: 10.1167/iovs. 16-20569

Trapnell, C., Pachter, L., and Salzberg, S. L. (2009). TopHat: discovering splice junctions with RNA-Seq. Bioinformatics 25, 1105-1111. doi: 10.1093/ bioinformatics/btp 120

Tripathi, V., Ellis, J. D., Shen, Z., Song, D. Y., Pan, Q., Watt, A. T., et al. (2010). The nuclear-retained noncoding RNA MALAT1 regulates alternative splicing by modulating SR splicing factor phosphorylation. Mol. Cell 39, 925-938. doi: 10.1016/j.molcel.2010.08.011

Uchida, S. (2017). High-throughput methods to detect long Non-coding RNAs. High Throughput. 6:12. doi: 10.3390/ht6030012

Ule, J., Hwang, H.-W., and Darnell, R. B. (2018). The future of cross-linking and immunoprecipitation (CLIP). Cold Spring Harb. Perspect. Biol. 10:a032243. doi: $10.1101 /$ cshperspect.a032243

Ule, J., Jensen, K. B., Ruggiu, M., Mele, A., Ule, A., and Darnell, R. B. (2003). CLIP identifies Nova-regulated RNA networks in the brain. Science 302, 1212-1215. doi: 10.1126/science.1090095

Ulitsky, I. (2016). Evolution to the rescue: using comparative genomics to understand long non-coding RNAs. Nat. Rev. Genet. 17, 601-614. doi: 10.1038/ nrg. 2016.85

Ulitsky, I., and Bartel, D. P. (2013). lincRNAs: genomics, evolution, and mechanisms. Cell 154, 26-46. doi: 10.1016/j.cell.2013.06.020

Ulitsky, I., Shkumatava, A., Jan, C. H., Sive, H., and Bartel, D. P. (2011). Conserved Function of lincRNAs in vertebrate embryonic development despite rapid sequence evolution. Cell 147, 1537-1550. doi: 10.1016/j.cell.2011.11.055

Uroda, T., Anastasakou, E., Rossi, A., Teulon, J.-M., Pellequer, J.-L., Annibale, P., et al. (2019). Conserved Pseudoknots in IncRNA MEG3 are essential for stimulation of the p53 pathway. Mol. Cell 75, 982-995. doi: 10.1016/j.molcel. 2019.07.025
Uszczynska-Ratajczak, B., Lagarde, J., Frankish, A., Guigó, R., and Johnson, R. (2018). Towards a complete map of the human long non-coding RNA transcriptome. Nat. Rev. Genet. 19, 535-548. doi: 10.1038/s41576-0180017-y

van Heesch, S., van Iterson, M., Jacobi, J., Boymans, S., Essers, P. B., de Bruijn, E., et al. (2014). Extensive localization of long noncoding RNAs to the cytosol and mono- and polyribosomal complexes. Genome Biol. 15:R6. doi: 10.1186/gb2014-15-1-r6

Ventola, G. M. M., Noviello, T. M. R., D’Aniello, S., Spagnuolo, A., Ceccarelli, M., and Cerulo, L. (2017). Identification of long non-coding transcripts with feature selection: a comparative study. BMC Bioinform. 18:187. doi: 10.1186/s12859017-1594-z

Wahlestedt, C. (2013). Targeting long non-coding RNA to therapeutically upregulate gene expression. Nat. Rev. Drug Discov. 12, 433-446. doi: 10.1038/ $\operatorname{nrd} 4018$

Wang, C., Gong, B., Bushel, P. R., Thierry-Mieg, J., Thierry-Mieg, D., Xu, J., et al. (2014). The concordance between RNA-seq and microarray data depends on chemical treatment and transcript abundance. Nat. Biotechnol. 32, 926-932. doi: 10.1038/nbt.3001

Wang, K. C., Yang, Y. W., Liu, B., Sanyal, A., Corces-Zimmerman, R., Chen, Y., et al. (2011). Long noncoding RNA programs active chromatin domain to coordinate homeotic gene activation. Nature 472, 120-124. doi: 10.1038/ nature09819

Wang, W., Ha, C. H., Jhun, B. S., Wong, C., Jain, M. K., and Jin, Z.-G. (2010). Fluid shear stress stimulates phosphorylation-dependent nuclear export of HDAC5 and mediates expression of KLF2 and eNOS. Blood 115, 2971-2979. doi: 10. 1182/blood-2009-05-224824

Watts, J. K., and Corey, D. R. (2012). Gene silencing by siRNAs and antisense oligonucleotides in the laboratory and the clinic. J. Pathol. 226, 365-379. doi: 10.1002/path.2993

Webster, A. L. H., Yan, M. S.-C., and Marsden, P. A. (2013). Epigenetics and cardiovascular disease. Can. J. Cardiol. 29:12.

Wen, S., Wei, Y., Zen, C., Xiong, W., Niu, Y., and Zhao, Y. (2020). Long noncoding RNA NEAT1 promotes bone metastasis of prostate cancer through N6-methyladenosine. Mol. Cancer 19:171. doi: 10.1186/s12943-020-01293-4

West, J. A., Davis, C. P., Sunwoo, H., Simon, M. D., Sadreyev, R. I., Wang, P. I., et al. (2014). The long noncoding RNAs NEAT1 and MALAT1 bind active chromatin sites. Mol. Cell 55, 791-802. doi: 10.1016/j.molcel.2014.07.012

Wilusz, J. E., JnBaptiste, C. K., Lu, L. Y., Kuhn, C.-D., Joshua-Tor, L., and Sharp, P. A. (2012). A triple helix stabilizes the $3^{\prime}$ ends of long noncoding RNAs that lack poly(A) tails. Genes Dev. 26, 2392-2407. doi: 10.1101/gad.204438.112

Wolska, M., Jarosz-Popek, J., Junger, E., Wicik, Z., Porshoor, T., Sharif, L., et al. (2021). Long Non-coding RNAs as promising therapeutic approach in ischemic stroke: a comprehensive review. Mol. Neurobiol. 58, 1664-1682. doi: 10.1007/ s12035-020-02206-8

Wu, Z., He, Y., Li, D., Fang, X., Shang, T., Zhang, H., et al. (2017). Long noncoding RNA MEG3 suppressed endothelial cell proliferation and migration through regulating miR-2. Am. J. Transl. Res. 9, 3326-3335.

Xie, Y., Liu, Y.-G., and Chen, L. (2016). Assessing protein-DNA interactions: Pros and cons of classic and emerging techniques. Sci. China Life Sci. 59, 425-427. doi: 10.1007/s11427-016-5046-1

Xu, E., Hu, X., Li, X., Jin, G., Zhuang, L., Wang, Q., et al. (2020). Analysis of long non-coding RNA expression profiles in high-glucose treated vascular endothelial cells. BMC Endocr. Disord. 20:107. doi: 10.1186/s12902-020-005936

Xu, X., Nie, J., Lu, L., Du, C., Meng, F., and Song, D. (2020). LINC00337 promotes tumor angiogenesis in colorectal cancer by recruiting DNMT1, which suppresses the expression of CNN1. Cancer Gene Ther. 2020, 1-13. doi: 10.1038/ s41417-020-00277-2

Yan, C., Chen, J., and Chen, N. (2016). Long noncoding RNA MALAT1 promotes hepatic steatosis and insulin resistance by increasing nuclear SREBP-1c protein stability. Sci. Rep. 6:22640. doi: 10.1038/srep22640

Yan, M. S.-C., Matouk, C. C., and Marsden, P. A. (2010). Epigenetics of the vascular endothelium. J. Appl. Physiol. 109, 916-926. doi: 10.1152/japplphysiol.00131. 2010

Yang, J.-R., and Zhang, J. (2015). Human long noncoding RNAs are substantially less folded than messenger RNAs. Mol. Biol. Evol. 32, 970-977. doi: 10.1093/ molbev/msu402 
Yang, L., Lin, C., Liu, W., Zhang, J., Ohgi, K. A., Grinstein, J. D., et al. (2011). ncRNA- and Pc2 methylation-dependent gene relocation between nuclear structures mediates gene activation programs. Cell 147, 773-788. doi: 10.1016/ j.cell.2011.08.054

Yap, K. L., Li, S., Muñoz-Cabello, A. M., Raguz, S., Zeng, L., Mujtaba, S., et al. (2010). Molecular interplay of the noncoding RNA ANRIL and methylated histone H3 Lysine 27 by Polycomb CBX7 in transcriptional silencing of INK4a. Mol. Cell 38, 662-674. doi: 10.1016/j.molcel.2010.03.021

Yeh, C.-F., Chang, Y.-C. E., Lu, C.-Y., Hsuan, C.-F., Chang, W.-T., and Yang, K.-C. (2020). Expedition to the missing link: Long noncoding RNAs in cardiovascular diseases. J. Biomed. Sci. 27:48. doi: 10.1186/s12929-020-00 647-w

Zeggini, E., Weedon, M. N., Lindgren, C. M., Frayling, T. M., Elliott, K. S., Lango, H., et al. (2007). Replication of genome-wide association signals in UK samples reveals risk loci for type 2 diabetes. Science 316, 1336-1341. doi: 10.1126/ science. 1142364

Zeng, R., Song, X.-J., Liu, C.-W., and Ye, W. (2019). LncRNA ANRIL promotes angiogenesis and thrombosis by modulating microRNA-99a and microRNA449a in the autophagy pathway. Am. J. Transl. Res. 11, 7441-7448.

Zhang, B., Arun, G., Mao, Y. S., Lazar, Z., Hung, G., Bhattacharjee, G., et al. (2012). The lncRNA Malat1 is dispensable for mouse development but its transcription Plays a cis-regulatory role in the adult. Cell Rep. 2, 111-123. doi: 10.1016/j.celrep.2012.06.003

Zhang, B., Wang, D., Ji, T.-F., Shi, L., and Yu, J.-L. (2017). cerebral infarction by activating NF- $\mathrm{B}$ signaling pathway in a. Oncotarget 8, 17347-17359.

Zhang, C., Ge, S., Gong, W., Xu, J., Guo, Z., Liu, Z., et al. (2020). LncRNA ANRIL acts as a modular scaffold of WDR5 and HDAC3 complexes and promotes alteration of the vascular smooth muscle cell phenotype. Cell Death Dis. 11:435. doi: 10.1038/s41419-020-2645-3

Zhang, H., Xu, H.-B., Kurban, E., and Luo, H.-W. (2020). LncRNA SNHG14 promotes hepatocellular carcinoma progression via $\mathrm{H} 3 \mathrm{~K} 27$ acetylation activated PABPC1 by PTEN signaling. Cell Death Dis. 11, 1-13. doi: 10.1038/ s41419-020-02808-Z

Zhang, X., Gejman, R., Mahta, A., Zhong, Y., Rice, K. A., Zhou, Y., et al. (2010). Maternally expressed gene 3, an imprinted Noncoding RNA gene, is associated with meningioma pathogenesis and progression. Cancer Res. 70, 2350-2358. doi: 10.1158/0008-5472.CAN-09-3885

Zhao, W., Liu, Y., Zhang, C., and Duan, C. (2019). Multiple roles of exosomal long noncoding RNAs in cancers. Biomed. Res. Int. 2019:1460572. doi: 10.1155/2019/ 1460572

Zhou, G., Hamik, A., Nayak, L., Tian, H., Shi, H., Lu, Y., et al. (2012). Endothelial Kruppel-like factor 4 protects against atherothrombosis in mice. J. Clin. Invest. 122, 4727-4731. doi: 10.1172/JCI66056

Zhou, L., Zhu, Y., Sun, D., and Zhang, Q. (2020). Emerging roles of long noncoding RNAs in the tumor microenvironment. Int. J. Biol. Sci. 16, 2094-2103. doi: $10.7150 /$ ijbs. 44420

Zhou, X., Han, X., Wittfeldt, A., Sun, J., Liu, C., Wang, X., et al. (2016). Long noncoding RNA ANRIL regulates inflammatory responses as a novel component of NF-кB pathway. RNA Biol. 13, 98-108. doi: 10.1080/15476286.2015.1122164

Zollbrecht, C., Grassl, M., Fenk, S., Höcherl, R., Hubauer, U., Reinhard, W., et al. (2013). Expression pattern in human macrophages dependent on 9p21.3 coronary artery disease risk locus. Atherosclerosis 227, 244-249. doi: 10.1016/j. atherosclerosis.2012.12.030

Conflict of Interest: The authors declare that the research was conducted in the absence of any commercial or financial relationships that could be construed as a potential conflict of interest.

Publisher's Note: All claims expressed in this article are solely those of the authors and do not necessarily represent those of their affiliated organizations, or those of the publisher, the editors and the reviewers. Any product that may be evaluated in this article, or claim that may be made by its manufacturer, is not guaranteed or endorsed by the publisher.

Copyright (c) 2021 Subramaniam, Nair and Marsden. This is an open-access article distributed under the terms of the Creative Commons Attribution License (CC BY). The use, distribution or reproduction in other forums is permitted, provided the original author(s) and the copyright owner(s) are credited and that the original publication in this journal is cited, in accordance with accepted academic practice. No use, distribution or reproduction is permitted which does not comply with these terms. 